\title{
Çağdaş Türk Resim Sanatında Göç Olgusu: Mehmet Başbuğ Özelinde Bakmak
}

\author{
Tuğba GÜNGÖR ${ }^{1}$
}

$\ddot{O} z$

Çağdaş Türk resim sanatı içerisinde figüratif çalışmalarıyla Mehmet Başbuğ’un resimlerinde göç olgusunun dikkat çekici bir yeri vardır. Bireylerin yetişmesinde, gelişmesinde doğduğu ve yaşadığı coğrafyanın yanı sıra kültür ve toplumun da büyük rolü bulunmaktadır. Yaşadığı, yetiştiği ortamdan kaçınılmaz olarak etkilenen sanatçı için, içinde bulunulan toplumsal süreçler eserlerde konu olarak ortaya koyulabilmektedir. Tarihin en eski dönemlerinden beri süregelen göç olgusu, birçok değişken altında varlığını sürdürmektedir. Çeşitli parametreler altında yetişen sanatçı için, insan ve toplum bileşkesinde göç gibi zorlu koşulların yarattığı eylemler, sanatsal duyarlllıkla dile getirilmektedir. Çağdaş Türk resim sanatında göç konusuna dikkat çeken ve bu hassasiyette eserler üreten değerli sanatçıların varlığ1 dikkat çekmektedir. Turgut Zaim, Nuri İyem, İbrahim Balaban, Nedim Günsür, Ramiz Aydın, Gülsün Karamustafa, Temür Köran ve birçok değerli ismin eserleri bu bağlamda önemini korumaktadır. Bu değerli sanatçılar arasında bulunan, kendine özgü başarllı bir sanatsal dille üretimler yapan Mehmet Başbuğ’un eserlerinde göç olgusu, sıkllkla yer verilen konular arasında olmuştur. Türk tarih, kültür ve değerlerini kaynak alarak çalışan Mehmet Başbuğ, güçlü bir kompozisyon ve desen altyapisiyla oluşturduğu eserlerinde yer alan figürlerle vurgulanmak istenen konuyu, zengin bir kültürel bilgi ve çalş̧manın ürünleri olarak sunmuştur. Bu çalışmada; göç üzerine değerli çalışmalarılyla dikkat çeken sanatçlardan bir seçkiye yer verilerek, figüratif Türk Resim Sanatı içinde önemli yeri olan Mehmet Başbuğ’un eserlerinde görülen göç olgusu irdelenmiştir.

Anahtar Kelimeler: Mehmet Başbuğ, Göç, Figüratif Türk resim sanatı

\section{Migration in Contemporary Turkish Painting Art: Review of Mehmet Basbug Case}

\begin{abstract}
Migration has a remarkable place in paintings of Mehmet Basbug with his figurative works of art within contemporary Turkish painting art. Culture and society have a significant role in individuals' upbringing and development as much as the geography in which individuals are born and live. For the artist who is inevitably affected by the environment in which he lives and grows, the social processes can be put forward as the subject of works of art. The case of migration, which has been going on since the earliest periods in history, has existed under many variables. For the artist who grew up under various parameters, the actions created by difficult conditions such as migration in the human and community compound are expressed with artistic sensitivity. In contemporary Turkish painting, the presence of valuable artists who draw attention to the issue of migration and produce works with this sensitivity draws attention. Turgut Zaim, Nuri İyem, İbrahim Balaban, Nedim Günsür, Ramiz Aydın, Gülsün Karamustafa, Temür Köran and many valuable names' works of art remain important in this context. Among these valuable artists, the migration variable has been among the topics frequently mentioned in the works of Mehmet Basbug, who produces artworks with his successful artistic language. Mehmet Basbug, who works by taking resources on Turkish history, culture and values, presented the subject that was emphasized with the figures in his works with a strong composition and pattern infrastructure as products of working and a rich cultural knowledge. In this study, a selection of Mehmet Basbug who attracted attention with their valuable work on migration was examined and the case of migration was examined as observed in the works of Mehmet Basbug with an important place in figurative Turkish Painting Art.
\end{abstract}

Key Words: Mehmet Basbug, Migration, Figurative Turkish painting art

\section{Atıf İçin / Please Cite As:}

Güngör, T. (2020). Çağdaş Türk resim sanatında göç olgusu: Mehmet Başbuğ özelinde bakmak. Manas Sosyal Arastirmalar Dergisi, 9(3), 1608-1626.

Geliş Tarihi / Received Date: 28.01.2020

Kabul Tarihi / Accepted Date: 04.03.2020

${ }^{1}$ Dr. Öğr. Üyesi - Süleyman Demirel Üniversitesi İletişim Fakültesi, gungortugba@hotmail.com ORCID: 0000-0001-5761-2708 


\section{Giriş}

İnsanlık tarihinin tüm dönemlerinde var olan bir olgu olarak göç; ekonomik, siyasal, kültürel vb. nedenlerle toplumsal yapının birçok dinamiği üzerinde etkili olmuştur. Günümüzde varllğını sürdüren göç olgusu, kuvvetle muhtemel gelecekte de varlığını korumaya devam edecek ve birçok coğrafya üzerinde etkisi görülecektir. Genel anlamıyla göç, sosyal, kültürel, ekonomik ve politik yönleriyle, coğrafi yer değişikliği sürecinde görülen toplumsal düzendeki farklılaşmayla gelişen nüfus hareketidir (Özer, 2004, s. 11). Türk Dil Kurumuna göre; "ekonomik, toplumsal, siyasi sebeplerle bireylerin veya toplulukların bir ülkeden başka bir ülkeye, bir yerleşim yerinden başka bir yerleşim yerine gitme işi, taşınma, hicret, muhaceret"tir (TDK, 2019). Göç, birey ve grubun siyasi veyahut simgesel çizgilerin dışına, yeni yerleşme sahalarına ve toplumlara yönelik kalıcı eylemlerini kapsamaktadır (Marshall, 1999, s. 685).

İnsanların göçleriyle dolu olan tarihte, genel olarak gönüllü ve zorla olmak üzere iki göç türünden bahsedilebilir. Sayısız faktörü içeren gönüllü devinimlerde özgürlük anlayışı ön planda olduğundan, kişiler üzerindeki etkileri zorla yaptırlana kıyasla daha farklı olmaktadır. Zorla yaptırlan devinimde; bireyin sürgün edilmesi, kişilerin toplama ve rezervasyon kamplarında alıkoyulması, köleleştirilmiş kişi ve grupların taşınması gibi çeşitli formları olabilmektedir. Büyük sanayileşmiş toplumlarda kırdan kente aralıksız bir akın görülmektedir. Bireylerin ülkeden ülkeye, bölgeden bölgeye yer değiştirme nedenleri çok ve karmaşık bir sürecin getirisidir. Ekonomik faktörler esas belirleyici olarak görülmekle birlikte, daha iyi yiyecek imkânlarına ulaşmak için göçebelerin, kazancı daha yüksek iş olanaklarına ulaşmak için işçilerin, yaşam standartlarını artırmak için ailelerin göç ettikleri söylenebilir. Tarımsal faaliyetlerde işçiye duyulan ihtiyacın azalması, bireyleri kırdan iterken, yükselen endüstrileşme bu bireyleri nüfusu bol olan birimlerdeki iş edinebilme olanaklarına ve gelişmiş yüksek standartlı yaşam şartlarına ulaşma isteği de benzer şekilde çekmektedir. Göç hareketliliğini güdülendiren ve ekonomik olmayan; dini, siyasi gibi ya da eğitim olanakları veya çalşsma ortamına uzaklık gibi birçok başka etken de vardır. Bununla birlikte göçün birey veya grup üzerinde çeşitli etkileri oluşmaktadır. Tarihsel anlamda bakıldığında göç olayının ciddi bir neticesi kültürün yayılma durumudur. Göç yoluyla kültürel ve coğrafi olarak yalıtılmış bireyler arasında temasa geçilmesinde ve iletişimde bulunulmasına öncülük eder. Göç aracıllğıyla, davranış örüntüleri alışverişe gidilir, yeni düşünce geliştirilir ve kültürün sınırları genişletilir (Fichter, 1996, s. 155-156). Bir mekân değiştirme durumu olan göçler, iç ve dış göç olarak iki farklı tabanda değerlendirilmektedir. İç göç, bir ülkenin kendi alanları dâhilindeki bir alandan başka bir alana yönelik olarak yapılan göç hareketidir. Diğer göç türü olan dış göç ülkeler arası yapılan göç durumudur. Bireyler kalıcı ya da geçici süreçlerle ve çeşitli nedenlere bağlı olarak bölgelerini değiştirmektedirler. Bu yer değiştirme durumu yıl içerisinde sistematik aralıklarla da yapılabilmektedir (Sağlam, 2006, s. 34). Göç çözümleme işlerimde itici etmenler çekici etmenlerden kökleşmiş olarak ayrışma göstermektedir. İtici faktörlerin çoğunlukla tutucu, emniyeti yükseltme amacıyla yapılan nedenleri oluşturduğu düşünülürken, aynı zamanda çekici faktörlerin daha risk alma edimine taraflı ve kazancı yükseltmeye yönelik bir göçü cazip kıldığı fikri yer edinmektedir (Marshall, 1999, s. 685).

Göçler yönleri bakımından çeşitli doğrultularda olabilmekte ve kimi ülkelerde seri ve yoğun bir kentleşme ve göç akışı oluşabilirken, kimi ülkelerde görece yavaş seyredebilmektedir. Türkiye'de 1950 yllından itibaren gerçekleştirilen göç hareketleri incelendiğinde çoğunlukla köyden kente doğru bir akışın olduğu bilinmektedir. 1980'den sonra mevcut seyrin yönünün farklılaştı̆̆1 ve bu akışın küçük şehirlerden daha gelişmiş kent yahut metropollere yönelik seyrettiği görülebilmektedir. Göç ve kent kavramıyla paralel anılan kentleşme, kentlerin ve kentlerdeki popülasyonun çoğalması olarak anlaşılabilir. Kentlerin mevcuttaki içsel nüfus artısıyla beraber, diğer bölgelerden olan göçlerle de kentlerin nüfusunu arttıran etkenlerden olmuştur (Sağlam, 2006, s. 35-39). Göçle birlikte 1950’li yllardan itibaren ivme kazanan kentleşme süreci belli bölge ve şehirlerde nüfusun yoğunlaşmasını beraberinde getirmiştir. İç göçlerle ekonomik yönüyle zayıf kalan bölgelerden batıya yöneldiği varsayllmaktadır (Taş ve Özcan, 2013, s. 289). Türkiye'de şehirleşme, sanayinin gelişmesinin sonucu olarak düzenli bir yapılanma içerisine yol alamadığından konut sorununu beraberinde getirdiği gözlenmektedir. Hukuk ve imar dışı çözümlenmeye çalışlan bu sorun gecekonduların görülmesine kaynaklık etmiştir (Sağlam, 2006, s. 40). Türkiye'de, 1980’li yıllardan sonra da terör olaylarının etkisiyle zorunlu göçler oluşmuştur. Doğu Anadolu ve Güneydoğu Anadolu Bölgeleri'nde göçler yaşanarak, hem bölgede hem de ülke genelinin sosyo-kültürel yapisında önemli değişikliklerin olduğu görülebilmektedir (Taş ve Özcan, 2013, s. 296).

Dış göç sürecinde Türkiye, öncelikle nüfus mübadelesi ile oluşan göçler hem göç alma hem göç verme bağlamında önemini korurken, Avrupa'da oluşan işgücü açığıyla ortaya çıkan işçi göçü dalgalarıyla 
göç veren bir konuma geçtiği görülmektedir. Batı Avrupa’ya yapılan göç 1961 senesinde öncelikle Almanya devamında başka İskandinav ve Batı Avrupa ülkelerine yönelik misafir işçi anlaşmalarıyla sağlanmış, kısa süre içerisinde büyük göç hareketliliğinin kaynağını oluşturmuşlardır. 1970’lerde misafir işçi sözleşmesinin feshi göç hareketliliğinin önünü almakta yeterli olamamıştır. 1980 yllındaki askeri darbe ve sonrasında gelişen Güneydoğu meselesi Avrupa'nın kimi ülkelerine iltica yoluyla Türk vatandaşı mültecilerin gitmesine ve işçi göçü yaşanmasına sebep olmuştur. Devamında ailelerin bir araya gelebilmeleri hakkında düzenlemelerin yapılması, göçlerin sürdürülmesine yol açmış ve farklı etaplardan geçen bu süreç kararlılık kazanarak Türk vatandaşı göçmenler için kalıcı yurttaşlar konumunu almasını sağlamıştır (Kaya, 2008, s. 163). Son dönemlerde Suriye'de yaşanan bunalım öncelikli olmak üzere çevrede yaşanan savaş ve çatışmalar ülkenin yoğun göç almasına kaynaklık etmiştir. Göç alan bir ülke konumuna dönüşen Türkiye, geçiş için kullanılan bir bölge olma özelliğini de üzerine almıştır. Türkiye, uluslararası göç hareketliliğinin merkezi olan kaynak, hedef ve transit bir ülke konumuyla anılmıs, 1950 ve 1970’li yıllar arasındaki göç veren ülke pozisyonu değişerek, dünyanın en büyük mülteci nüfusunu barındırma konumuna bürünmüştür. Bu göç dalgalarına sebep olan durumlar şu şekilde özetlenebilmektedir. Asya ve Afrika ülkelerindeki politik ve iktisadi istikrarsızlık, çatışma gibi olumsuz koşullar neticesinde ülkelerinden ayrılan kişiler ve diğer ülkelere gidebilme kaygısıyla ülkeyi geçiş bölgesi olarak gören kişilerin oluşturduğu hareketliktir. Ekonomik olarak güçlü olan Türkiye'de bavul ticareti yapmak isteyen kişiler, bundan başka Doğu Blok'u ülkelerinden izinli ya da kaçak yollarla ülkede kalma ve Orta Asya Türk Cumhuriyetleri'nden gelen işçi olarak barınma amacı bulanan kişilerin oluşturdukları göç dalgasıdır. Küreselleşme süreciyle birlikte gelişen ülkeler arasındaki sınırların silikleşmesiyle ülkeye gelen kişilerin göç hareketliliği ve Suriye İç Savaşı sonucunda oluşan kitlesel olarak göç eden Suriye vatandaşlarının Türkiye'de bulunması hareketlilik dalgalarının önemli sebeplerini oluşturmaktadır (Aygül, 2018, s. 69-70). Günümüzde devam eden göç yapılanmasının toplumsal yapıyı derinden etkilediği görülmektedir.

Bir nüfus hareketi ve mekân değiştirme eylemi olarak göç, açıklanması kolay olmayan ilişkiler bütününü içinde barındırmaktadır. Bu özelliğiyle kültürlerarası etkileşimde aktif rol oynamakla birlikte hayatın içinde bir gerçeği sunmaktadır. Göç olgusunu daima bünyesinde barındırmış bir millet olan Türkler için bu olgu, neredeyse Türklük kavramıyla birlikte anılan bir durum haline gelmiştir. Çeşitli sebeplerle Türkistan'dan Akdeniz'e oradan da Avrupa'ya yayılan Türkler, göçün izlerini üzerinde taşıyarak tarihteki yerini almıştır (Şen, 2014, s. 232). Zengin geleneğe sahip bir millet olan Türklerde yaylak ve kışlak hayatı önemli bir yer tutmaktadır. Hayvancılıkla yakinen muhatap bir toplum olan Türkler için en temel göç eylemini süreklilik içeren yaz ve kış aylarına ayak uydurularak iklim koşulları doğrultusunda, yüksek ve alçak bölgeler arasında süregelen bir döngü içinde yaptıkları bilinmektedir. Göç; sosyal, kültürel, ekonomik gibi unsurları etkileyen, dönüştüren, yeni oluşumların doğmasına gebe bir süreci de tanımlamaktadır. Her ne amaçla yapılıyor olsa da gidilen coğrafyaya beraberinde götürülen kültür ve medeniyet birikimi bölgenin dinamiğini etkilemekte ve değişimin yaşanmasına kaynak oluşturmaktadır. Benzer şekilde, varılan coğrafyanın dinamikleri bölgenin yeni konuklarını karşlıklı olarak etkilemekte ve aktif bir ilişkiler yumağına dönüştürmektedir. İçinde hareket gibi birçok öğeyi barındırması özelliğiyle kültürlerarası oluşumları etkileyen, yeni dönüşümlere olanak sağlayan ve kendinden sonraki süreci de etkileyebilen bir yapiya sahip olan göç vasıtasıyla kültürler gelişip, şekillenebilmekte ya da silinebilmektedir. Var olan sistematiğinden göç vasitasıyla kopan birey ya da grup için gidilen yeni mekân, yeni kapsamların kazanılması anlamına gelmektedir. Bireyin psikolojik, sosyal vb. yapılarını yeniden güncellemesine kaynak olan bu eylem biçimi, bellekte geçmesi kolay olmayan emareler bırakmaktadır. Bu belirtileri önemli kılan ise göçün içinde barındırdığı, bireyin ona yüklediği anlamdır. Öyle göçler vardır ki içine kocaman bir yaşanmışlığı alır. Acı, sevinç, hüzün, yıkım, mutluluk, yalnızlık gibi insani değerlerle kendine nitelik kazandırmaktadır. Sosyal bir varlık olan sanatçı için göç, kimi zaman kendi yaşanmışlıklarından, kimi zaman tarihin referanslarından, kimi zamansa sadece içsel duyarllı̆̆ından beslenme kaynağı olabilmektedir. Birçok sanat disiplini altında işlenen göç olgusu, çağdaş Türk resim sanatında en seçkin örneklerini vermeye devam etmektedir.

\section{Göç Olgusu ve Çağdaş Türk Resim Sanatındaki Eserlere Yansıması}

Sanat ve göç olguları yaşamsal süreçte kesintisiz yer almaktadır. Ekonomik yaşamdan kültüre değin yaşam döngüsünü tüm yönleriyle etkisi altına alan göç, temel değişim vasıtasıdır. Diğer yönden sanat, insan varlığının öznel bir tavrı olmasının aksine, bu durumun yapılanmasında sosyal dinamiklerin gücü göz ardı edilemez bir gerçekliktir. Bu sebepledir ki; göç olgusunun toplumun inşa edilmesinde önemli bir faktör olarak etkisini dolaylı ya da dolaysız bir şekilde sanat olgusuna yansıtması gündeme gelmektedir (Gönülal, 2007). Göç olgusunun sanata yansımasına insan ekseninde bakıldığında göç eden bireylerin kişisel 
hatıraları, grupların kolektif tarih bilinci ve kimliği görsel bir ifade yöntemiyle sanat tarihindeki yerini alırken, konuya dikkatleri çekerek aynı zamanda bir farkındalığın oluşmasına da kaynaklık etmektedir.

Yaşanmışlık durumuna göre bireyin bilinçaltında çok derin izler bırakabilen göç, özünde bir şeyi geride bırakmayı gerektirir. Bir belirsizlik durumuna doğru yönlenirken, bir dönüşümün öteki ismi olur. Her durumda göç kavramının altında zorunlu bir mekân değişikliği yatmaktadır. Doğasında yaşanılan yeri terk etmek vardır. Göç eylemine sebep olan durumlar aslında göç ettirmeyi zorlayan sebeplerdir. Göç içinde yaşanılan, alışkanlık haline gelen yerleşim yerini terk etmektir. Daha da önemlisi, sevdiklerinden, dilinden, kültüründen vazgeçmektir (Atan, 2019). Kimi göçler beraberinde yeni bir hayata karşı gösterilen umuda kavuşma çabasını, gerçekleșmesi beklenen hayalleri niteleseler de; daha çok yaşam koşullarının zorluğu karşısında yüklenilen, öncelikle kederi, yok oluşu öne getiren ve bu durum altında yaşanan aşılması gereken zorlu bir engel sürecini akıllara getirmektedir. Yaşamın bir yerinde varllğını koruyacak bir serüven olan göç, ardında bırakılanları, gelenekleri, alışkanlıkları, korkuları, öncelikleri, aşina olunan birçok değeri hatırlayıp, yaşanmışlıklar bütününe çevrilmesine kaynaklık etmektedir. Göç sürecini doğuran yol serüveninde, yitirilmiş yaşamlar, küçük çıkınlara sı̆̆dırılmaya çalışılan kocaman hatıralar, parçalanmış arzular, eksikliği hep hissedilen bir bütünün kesitlerini oluşturmaktadır.

Sanat pratiğinde göç olgusu modern dönemlere kadar genellikle iki esas üzerine temellenir. İlki daha ilk çağlardan bireyin daha nitelikli iklim koşullarında yaşamını sürdürebilmesi için çabaladığı arayış sürecidir. Devamında gelen aşamalı süreç göç deneyimlerini birlikte getirmiştir. Savaşlar ise ikinci temeli oluşturmaktadır. Çeşitli sebepler altında çıkan savaşlardan etkilenen insanoğlu, savaşın yıkıcı özelliklerini hem bireysel hem de toplumsal boyutlarıyla yaşar ve kaçınılmaz olarak göçe zorlanır. Birçok deneyimle göçe tanık olan birey, politik ve kültürel manada bir hayli yapıyı da yeni yerleştiği yere taşımaktadır. Modern dönemde bu olguya kentleşme kavramı farklı bir boyut kazanarak eklenmiştir (Öner, 2016, s. 42). Göçün doğurduğu birçok sosyolojik, ekonomik, psikolojik gibi nedensellikler sanatsal çalşmaların gündeminde estetik duyarllıkta sunulmaktadır. Günümüze kadar Türk resim sanatı içerisinde birçok sanatçının göç olgusunu çalışmalarına taşıdıkları görülebilmektedir. Bireysel sanat pratiklerinde uygulanan göçe öznel yaklaşım, odaklanılan bu tema ekseninde birçok zenginlikle birlikte sunulmasına kaynaklık etmiştir.

Bu zenginliklere yerinde olabilecek başarlı örneklerden birine Turgut Zaim (1906) verilebilmektedir. Köy yaşamını minyatür esinleriyle yorumlayan sanatçı, konu seçiminde öncelikle Anadolu köylüsüne yönelmiş ve eserlerinde anıtsal bir boyut kazanarak figüratif anlatımlara önem vermiştir. Folklorik konulara yönelen sanatçı, göçerler ve köylülerin mutlu yaşam kesitlerini ayrıntılarından yalıtılmış form düzeneğiyle belirgin bir şekilde ortaya koymakta ve yörükler gibi ele aldığı tüm konular sanatçının öznel yorumuyla tuvallerde yeniden yaşamsallık kazanmaktadır (Giray, 2000, s. 414). Tanıkçı bir netlik, samimiyet ve duyarllığını eksiltmeyen bir devamlılıkla Anadolu köylüsüyle, göçerlerin yaşamından kesitleriyle başarılı çalışmalar yapmıştır (Tansuğ, 2005, s. 174-175). Eserlerinde seçtiği imgeleri, Anadolu kültürünün bir yansıması olarak düşünülebilecek çalışmalarında kendine özgü bir ifade dili yakalamıştır. Bu üslupsal ifade dili geleneksel form iradesine sadık kalınarak ve çağdaş bir anlatım karakterinin sınırlarında geliştirildiği görülmektedir. Anadolu yaşamında var olan göçerlerin doğal yaşam döngüsü içine yerleşen yazlık kışlık hayatın getirdiği göç olgusunun yansımaları sanatçının eserlerinde gizil olarak kendine yer edinmiştir. "Yaylada Yörükler" isimli eserinde Yörük yaşamından bir kesit verilmiştir. Arka planda yerleşik bir mekânın izleri sürdürülürken, ön planda keçileriyle birlikte şehirden uzakta bir alanda bulunan bir grup insan figürü görülmektedir. Çalışmalarının konu bakımından serüveni incelendiğinde, değerlendirilen esere verilen isimden de bir çıkarıma varılabileceği gibi, göçer toplumların bir uzantısı olarak yaylaya yapılan göç sonrası anlık bir sürecin sunulduğu görülmektedir. Sanatçının tipik olarak mutlu insan görünümleri eylem içindeki figürlerin yüzlerinden okunabilmektedir. Eserde ön ve arka planlara yerleştirilen imgeler vasitasıyla yaylak ve kışlak hayatın etkileşim ve zamansal olarak dönüşüm içinde olan ilişkisi örtük bir biçimde verilirken göç olgusu yan anlamsal boyutuyla okunabilme imkânı sunmaktadır. 


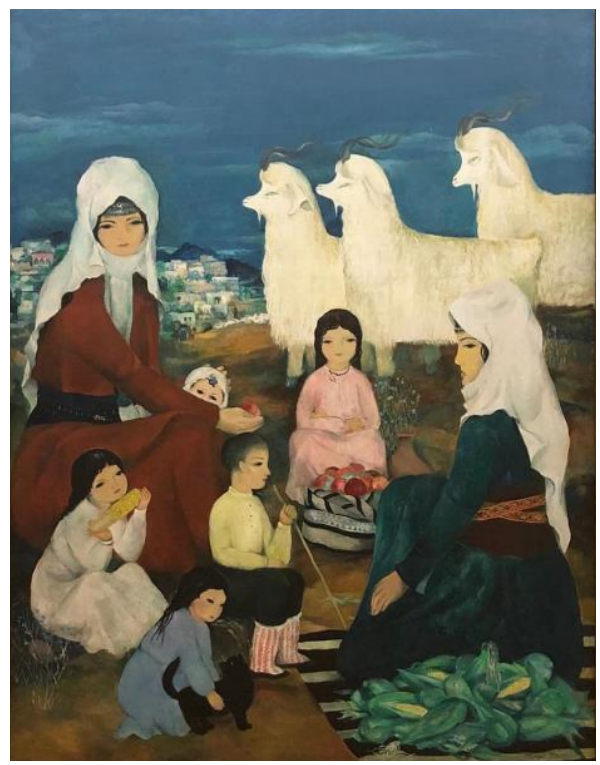

Resim 1. Turgut Zaim, Yaylada Yörükler, $175 \times 135$ cm, T.ü.y.b., 1962. (Satılmıs, 2019, s. 17)

Göç ve göçün insan üzerindeki etkilerini kendine sanatsal bir çıkış yolu edinen Nuri İyem (1915), bu konuda çok sayıda eser veren sanatçılar arasındadır. Sanatsal yaşam çizgisi içinde birçok üslup çeşitlemesinde üretimler yapan Nuri İyem, özellikle 1960 sonrası Anadolu insanını, bu insanların yaşayış şekillerini inceleyen şahsına has figür anlatısı geliştirme amacı içinde olmuştur (Erdemci, Germaner ve Koçak, 2008, s. 78). Sanatçı, resimsel içeriğin anlamını vurgulayan açı ve dolaysız içtenliğge perde olan hiçbir gösterime ödün vermeden, samimi ilişkileri, katışıksız duyguları resimlemiş, teknik yetenekler, sanatsal eylemler ve renkler resme hâkim olan saf içtenliği desteklediği ölçüde dâhil edilmiştir. Doğaçlama bir anlatımın ürünlerine yaklaşan bir ustalıkla sergilenen eserlerin en önemli niteliği, yoğun bir duygu aktarımını gerçekleştirme başarısının yakalanmış olmasıdır (Giray, 2000, s. 438). Nuri İyem'in "Gecekondular Önünde" isimli çalışmasında şehre göç sonucu oluşan gecekondulaşma sorununu ele almış ve bu hikâyenin özünde aslında büyük kente göçü temsil ettiği anlaşılmaktadır. Kitleler halinde göçen insanları ön planda tutarken, orta planda yine kitleler halinde gecekondu yapılarını ve aynı şekilde arka planda kütlesel bir biçimde yüksek katlı apartmanları konumlandırmışıtır. Olabildiğince canlı renklerin seçildiği eserde insan, gecekondu ve apartmanlar birbirinden kolaylıkla ayrrlabiliyorken, figürlerin yüz ifadesi ve duruşlarından içinde bulundukları psikolojik durumları samimiyetle aktarılmaktadır.

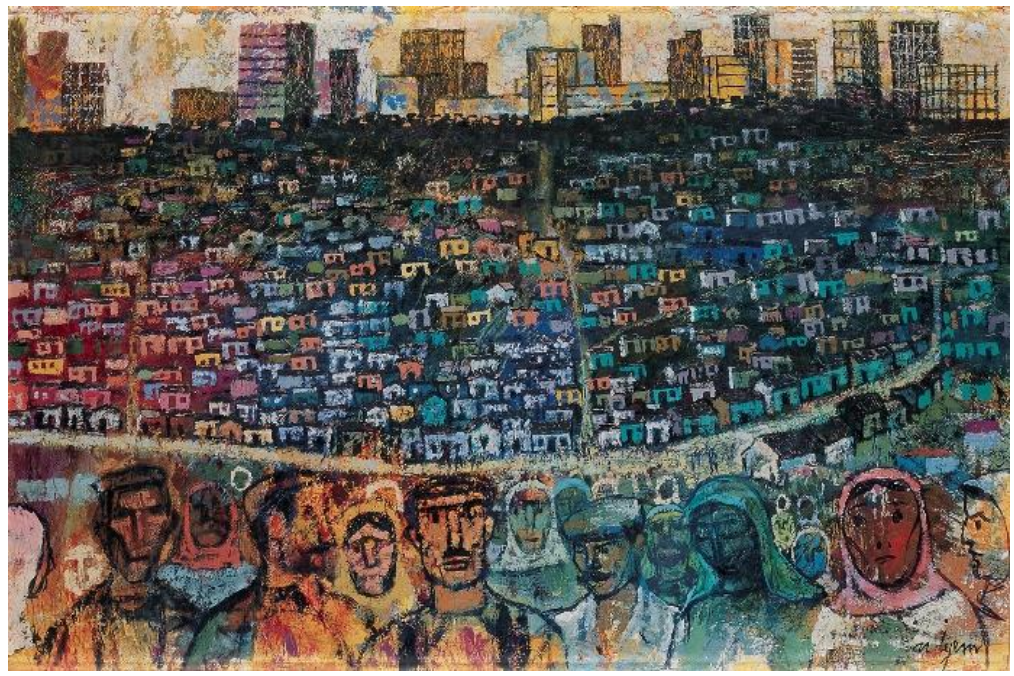

Resim 2. Nuri İyem, Gecekondular Önünde, 58×38,5 cm, Duralit üzerine yağh boya, 1970 (nurizyem.com, 2020)

Anadolu insanın toplumsal-psikolojik yapısını dile getirdiği çalışmalarıla öne çıkan sanatçı, göç temasını çalışmalarında sıklıkla kullanmıştır. "Göç" isimli eserinde klasik figüratif anlatım özellikleri içinde desen, kurgu, renk nitelikleri sağılklı bir devinim içinde yerlerini almışır. Boya katmanlarının gözlenmesine imkân sağlayan teknik yaklaşım, renklerin açık-koyu dengesi, kurgu düzlemi içerisinde ritim sağlayarak pentüre dönüşmüştür. Hareketli bir oluşum içindeki eser, anlam bütünlügüne referans olan imgeleri bir 
arada aktararak, yaşamın devingen değişimini gözler önüne sererken, insanların göçle birlikte yaşamış olduğu güçlü duygu durumları aktarılmıştır.

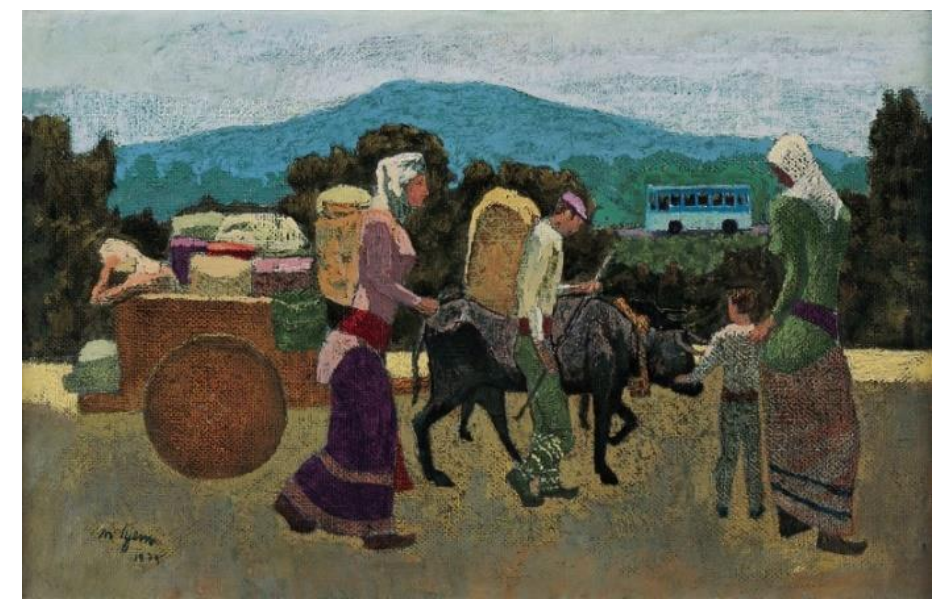

Resim 3. Nuri İyem, Göc, $56 \times 36$ cm, Duralit üzerine yağh boya, 1975 (nuriiyem.com, 2020)

Sanat yaşamı içerisinde birçok dönemi olan İbrahim Balaban (1921), dayanağını yaradılış öyküsünden, köy yaşamının büyüsünden, Anadolu insanının özgünlüğünden ve göç gibi yaşamın gerçeklerinden aldığ1 çalışmalarında insana ve hayata dair kesitler sunmuştur. Çalışmalarının estetik yapılandırmasını, yaşamsal deneyimleriyle birlikte; toplumsal ve sınıfsal çelişkiler, Anadolu insanının hem doğa hem de kendisini baskılayan güce karşı direnişi gibi temalarla temellendirmiştir. Sanatçı bilindik kalıplardan sıyrılarak, şema resminin dışında resimsel bir dinamizm yaratmayı başarmıştır. Kendine özgü geliştirdiği üslubunda kullandığ1 canlı renklerle, kurguladığ1 kompozisyonlarda hüzne yer bırakmadan mutlulukla doldurmuştur (Balaban, 2011, s. 104-105). Otodidakt bir ressam olan İbrahim Balaban eserlerinde figürlerini boyarken açık koyu endişesine kapılmamayı ve figürlerin varoluş yapısına aksi bir durum yaratmamayı seçmiştir. Figürlerinde naif sanat anlayışının bir yansıması olarak anatomik çarpıtmalarla bir deformasyon izlenmekte ve bu çarpıtmalar sanatçının resimsel yaklaşımının özelikleri arasında olmaktadır (Ersoy, 1998: s. 164). Kendine has üslubuyla yarattığ "Göç" isimli çalışmasında ailece çıkılan yol hikâyesi ele alınmıştır. Çıplak ayaklı yetişkin figürlerin sırtlandığı bohçalar ve çocuklar, göçün ne denli zorlu bir süreci gerektirdiğini gözler önüne sermektedir. Resmin oluşumunda yararlanılan biçimsel dil, figürlerin içinde bulunduğu ruh hallerini yansıtmış, fantastik bir kurgu içerisindeki figürlerin güçlü bir ritim içinde yerleştirilmesine olanak sağlamıştır. Sanatçının renk seçimindeki içgüdüsel yaklaşımı resmin anlamını güçlendirmiş ve yapısal bütünlüğünün etkisini arttırmasına olanak vermiştir.

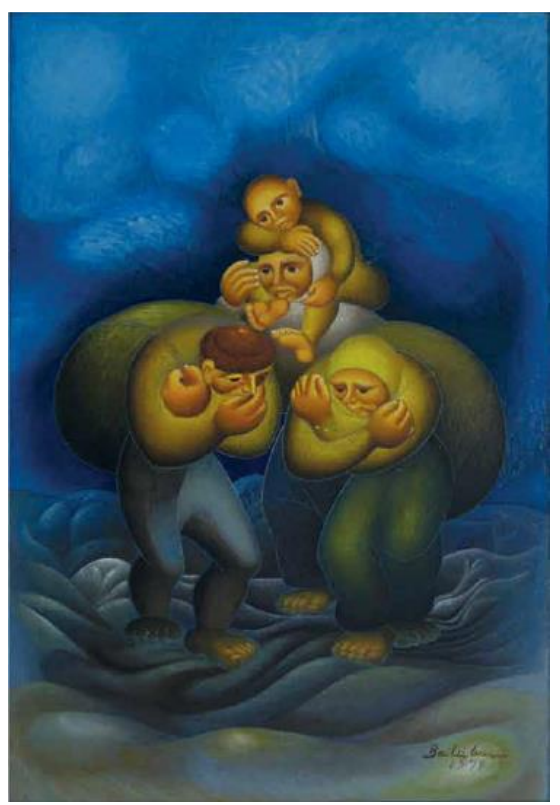

Resim 4. İbrabim Balaban, Göc, 100x70, Duralit üzerine yağh boya, 1978 (Balaban, 2011, s. 21) 
Bir Rönesans sanatçısı hassasiyetiyle figüratif resimler yapan Neşet Günal (1923) toplumcu gerçekçi bir anlayışla Anadolu insanını ve yaşantısını yorumlamıştır. Bilinçli bir gözlem sürecinden geçirdiği sorgulamalarıyla üretimler yapan sanatçı, ağır oturaklı ve abartılmış deformasyonla belirlenen desenlerle, pastel ton ve standartlaşmış renklerle Anadolu insanının ve toprağının tüm özelliklerini titizlik ve sabırla işlemiştir (Ersoy, 1998, s. 82). Sanatında belirli bir ulusallık ve bölgesellik aşılayan sanatçı, Anadolu insanının yaşantısından kesitler sunmuştur (Berk, 1972, s. 37). "Mola" isimli eser incelendiğinde hane halkının göç eylemine tanık olunmaktadır. Ailenin göç ederken verdiği bir mola anını resmettiği görülmektedir. Eserde sol tarafta erkek figürü yerleştirilmişken, kadın ve çocuk diğer tarafa doğru konumlandırılmıştır. Çocuk anneyle ilişkilendirilmiştir. Kadın ve çocuk yorgunluklarını oturup dinlenerek giderirken, erkek figürün ayakta betimlenmesi kente ulaşıldığında ilk çalşsacak olan bireyin kendisi olacağ1 mesajı olarak yorumlanmaktadır. Kadına atfedilen simgesel olarak emek yoğun işlerde hizmet vereceği olmaktadır. Arka planda aşılması gereken tepeler zorlu yaşam mücadelesinin ipuçlarını vermektedir (Karkıner ve Ecevit, 2012, s. 220). Günal'’n eserlerinde göç eyleminin öncesi ve sonrasındaki etkilerini görebilmek olasıdır. Göç anını eserlerine sıklıkla yansıttığı söylememek zor görünmesine rağmen, göç hareketinin bir sonucu olarak gelişen zorlukların ve acıların insan üzerindeki yansımalarıla, yaşanabilecek muhtemel göç eyleminin olasıllğı dramatik ve tüm detaycıllğ̆yla işlendiği duyumsayabilmektedir.

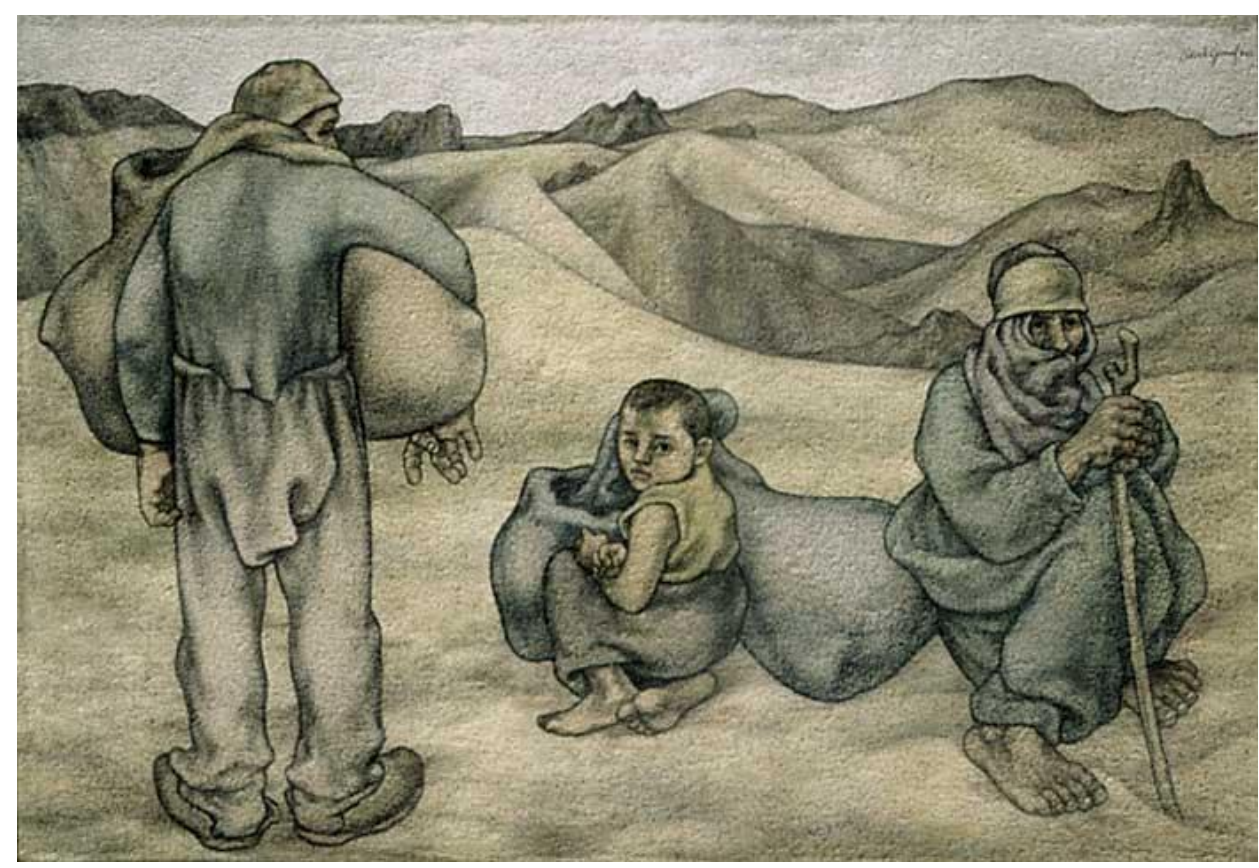

Resim 5. Neşet Günal, Mola, $139 \times 210$ cm, T.ü.y.b., 1962 (Karkener ve Ecevit, 2012, s. 220)

Çağdaş Türk sanatı içinde özgün bir yeri olan Hüseyin Bilişik’in (1923) çalş̧maları içerik ve biçim bakımından tutarlılık göstermiştir. Sanatçı, göç konulu bozkır resimlerinde içeriği ulusal nitelikler taşıyan bir resim dili oluşturma amacı içerisinde olmuştur. Doğu Anadolu yöresinin çile çeken kırsal yaşamından derlediği görüntülerde insanın toprakla olan mücadelesini alışılageldik bir anlatım yöntemiyle işlemiş, insan-toprak ilişkisini ikisi arasındaki tükenmeyen mücadeleyi işaret etmiştir. İstifleme biçiminde bir kompozisyon kurgusu içinde toprağın rengi olan kahverengi ve çeşitli tonlardaki yeşilin kullanıldığı bir renk skalası hâkim olmuştur. Sanatçının $80^{\prime} l i$ yıllarda ürettiği yapıtları değişime uğrayarak, büyük renk lekeleriyle parçalanmış kompozisyonlara dönüşmüş, daha canlı ve coşkulu renk anlayışıyla soyuta evrilmiştir. Kullandığı plastik öğeler bir Yörük çadırı ya da bir tarım aracından bir detay olarak yine gerçeklerden beslenmiştir. Ancak hangi konu veya üslupta çalışırsa çalışsın eserlerinin arasındaki organik ilişki varllğını hep korumuştur (Ersoy, 1998, s. 83). 1989 yllından itibaren farklı sanat eğilimleri altında çalışmalar yapmış, ileriki aşamalarda çok boyutlu düşünce dinamizmini veren anlayıştaki çalsşmalarını sürdürmüştür (Gültekin, 1992, s. 188). "Göçebeler" isimli eserde figürler eylem içerisinde aktarılmıştır. Uzun bir hikâyenin öznesi niteliğindeki göç eden figür grubu kompozisyonun merkezine yerleştirilmiş, çalşsmada yerel motiflerle renkler ön plana çıkartılmış ve yöre peyzajının kimliğinden yararlanılmıştır. 


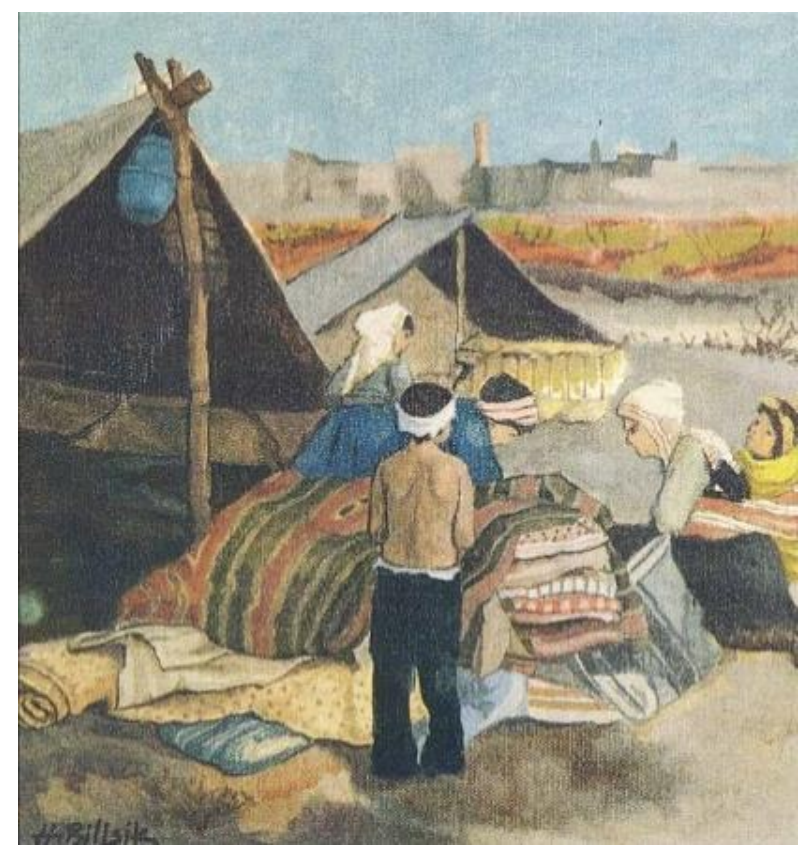

Resim 6. Hüseyin Bilişik, Gögsebeler, T.ü.y.b. (istanbulsanatevi.com, 2019)

Toplumsal içerikli resimleriyle çağdaş Türk sanatında kendine yer edinen Nedim Günsür (1924), yerel duyarlıkları özümseyen yaklaşımıyla özgün figüratif resim çalışmaları yapmıştır. Günsür'ün İstanbul'u, köyden kente göç sürecini ve bunlarla birlikte göç eyleminin birlikte oluşturduğu gecekondulaşma kavramı gibi meseleleri aktardığı çalışmaları da toplumsal kökenli ürünleri kapsamında yer almaktadır (Erdemci vd., 2008, s. 140). Günsür'ün sosyal olaylar ve göç ile ilgili birçok önemli eserinin arasında, İstanbul resimlerinde bir önemli eseri de "Gurbetçiler" adı altında toplanmıştır. Almanya'ya gönderilen Türk işçilerinin dramını irdeler ve resimlerinde bu izleğin izleri bulunur. 1960’larda yaşanan kentleşme olgusuyla birlikte başlayan batıya insan gücü göçü, birçok sanatçının eserlerine malzeme olurken, Günsür'ün de güncel konuları arasına girmiştir (Giray, 2000, s. 490). Avrupa'ya insan göçünün yaşanması, toplumsal bir gerçeklik olarak sanatçının göç ve göçün getirdiği süreçler bağlamında duyarlı çalışmalarının içinde yer bulmuştur. Daha güzel yaşama kavuşma arzusuyla göçen insanlar, eserde "İstanbul-Frankfurt" seferini yapmakta olduğunu refere eden trenin önünde hareket halinde yerleştirilmişlerdir. Tren penceresinin dibinde gurbete yol alacak olan kocasını yolcu eden kadın ve çocuklar, çaresi olmayan bir durumun oluşturduğu toplum gerçeğini duyumsatmaktadır. Göç eden gurbetçi, umutsuzluk ve bıkkınlıktan öte, zorluk ve çaresizliğe direnen bir formda sunulmuştur. Mekâna dair bilginin sunulduğu eserde trenin hareket yönü de anlaşılabilmekle birlikte, yetşskin ve çocuk grupların içinde bulunduğu farklı insan çeşitlemeleri yaşamdan izler barındırmaktadır (İşanç, 2008, s. 62-63). Gerçekçi bir anlatımın öğelerini barındıran eser, dağınık ama kalabalık figür grubuyla oluşturulmuştur. Resimdeki figürlerin göçün getirdiği yapının üzerindeki psikolojik etkisi duru bir sanatsal dille sunulmuş, kullanılan renk değerleriyle durum pekiştirilmiştir. Sade bir üslupla göçe dair ciddi ipuçlarının verildiği eserin içeriğigle biçimsel düzenlemesi arasındaki bağ denge içinde sunulmuş, yakalanan ritim olgunluğuyla çalışma nesnel görüntüsünün arkasında anlamsal olarak da zengin bir görünüm kazanmıştır. 


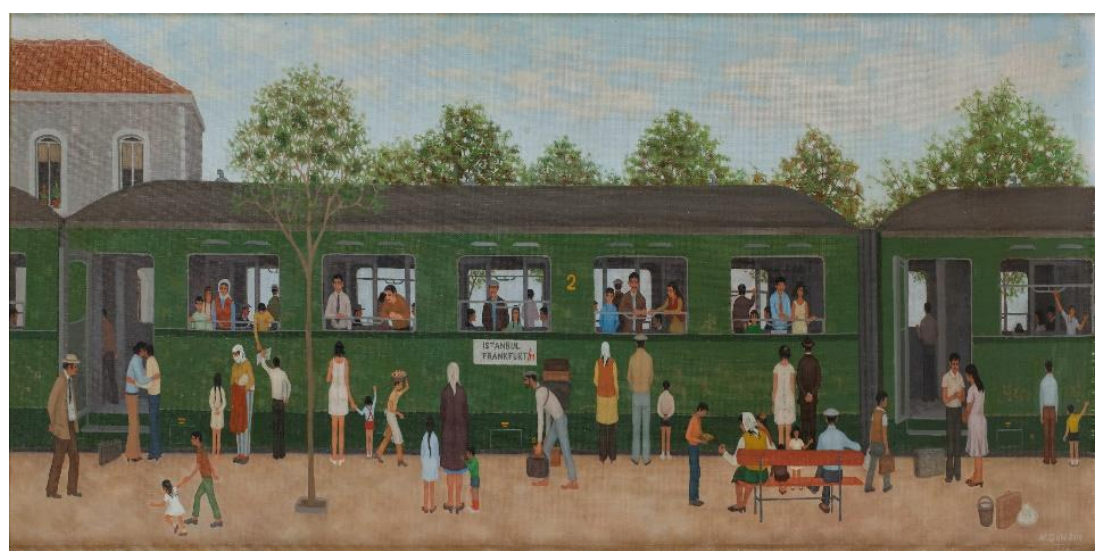

Resim 7. Nedim Günsür, Yeşil Tren / İstanbul - Frankfurt, $80 x 40$ cm, T.ü.y.b. (blog.peramuzesi.org.tr, 2020)

Çağdaş figüratif resmin önde gelen bir isimi olan Cihat Aral (1943), toplumsal gerçekleri işlerken eleştirel bir yaklaşım sergilemiş, kendine özgü sanatsal anlatım diliyle açlık, savaş, göç, yoksulluk, zulüm gibi her toplumda ve her dönemde insanlığın yaşadığı acıları irdelemiştir. Tanığ1 olduğu, deneyimlediği yaşantısını çalışmalarına aktararak insan ve yaşam gerçeğini resimlerinin içeriğine almıştır (Ersoy, 2004, s. 45). Çalışmalarının merkezine insanı alan sanatçı "Göç" isimli yapıtında görüntünün ötesinde derin bir anlam örüntüsü yattığı algılanmaktadır. Toplumsal olaylardaki kargaşa içinde insan varllğını betimlerken toprak renginin tonlarından yararlanmış, çölde görülen serap misali ulaşılmak istenen bölgeyi çekici ve umut verici kılmak adına canlı renkleri dahil etmiştir. Her ne kadar umut verici imgeler varlığını ispatlamaya çalıssalar da resmin geneline hakim olan kahverengi, sıkıntılı ve belirsiz bir durumun altını çizen göstergeler olmuştur. Olanca gerçeğiyle bir dramı sunan eser, sürecin devamının ne olacağına dair merak uyandıran imgeleriyle izleyiciyi içine çekmeyi başarmış görünmektedir.

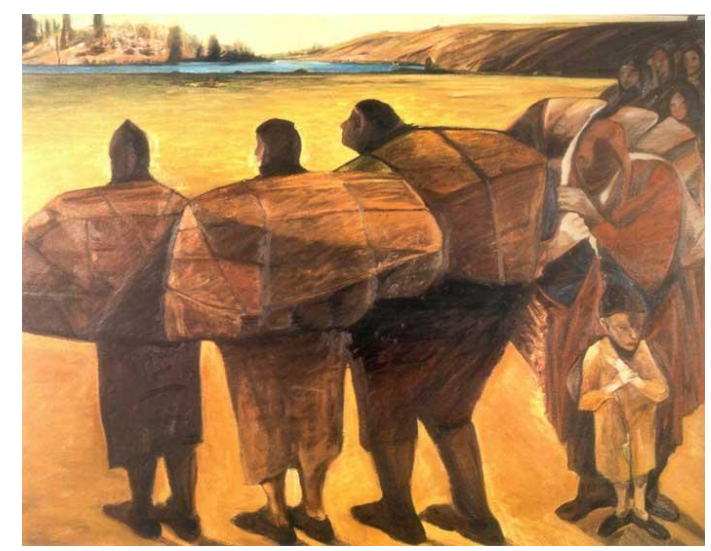

Resim 8. Cihat Aral, Gög, $115 \times 147$ cm, T.ü.y.b., 1995, TCMB Koleksiyonu (wnw.turkishpaintings.com, 2019)

Toplumsal içerikli eserleriyle tanınan Ramiz Aydın (1937) yaşadığı toplumun sorunlarını ve çelişkilerini tuvallerine aktarmış, kırsal kesimin yürüyen, yük taşıyan, güçlü, sağlam ve dürüst insanlarını idealize ederek anıtsallaştırmıştır (Ersoy, 1998, s. 87). Öner’in (2016, s. 49) çalışmasında, sanatçının göç temasını konu alanı olarak irdelemesinin özünde Aydın'ın toplum ve insan duyarlılıklarının rolü bulunduğundan bahsetmiştir. Ramiz Aydın'la yaptığı kişisel görüşmesinde sanatçı; göç için hem toplumsal bir sorun hem de umut olarak yorum yapmış, göç edenlerin çaresizliğinden duyduğu üzüntüyü dile getirmiştir.

Ramiz Aydın’ın az renk ve pastel tonlarının ağırlıklı olarak kullanıldığı “Göç” isimli eserinde kalabalık bir figür grubu yer almaktadır. Geniş bir düzlük içinde sıralanan figürlere arka planda yatay bir ufuk çizgisi eşlik etmektedir. Abartısız ve gerçekçi bir kurgu içinde dış dünyanın nesnel görüntüleri sanatçının kişsisel ve tinsel duyarllilığında sunulmuştur. 


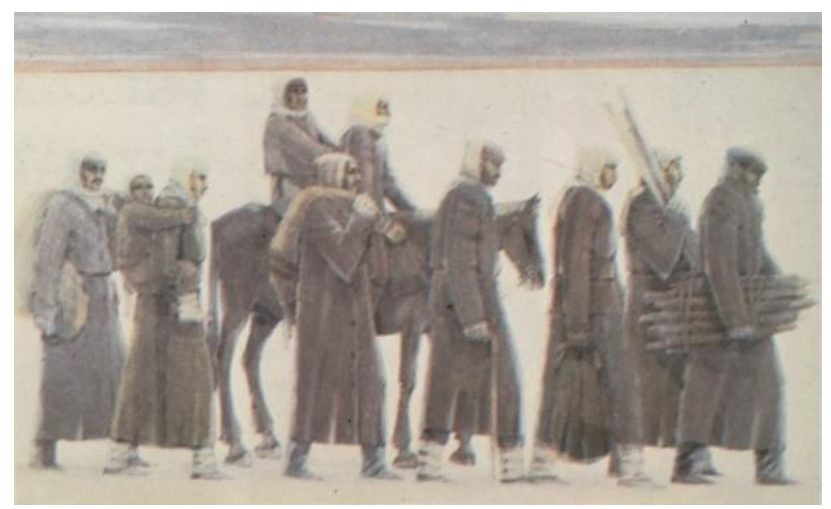

Resim 9. Ramiz, Aydn, Gös, T.ü.y.b., Özel Koleksiyon (Tansuğ, 2005, s. 304)

Gülsün Karamustafa (1946), toplumsal yaşam içerisinde bir sorun olarak beliren göç ve göçün sosyokültürel etkilerini 1970’lerin ikinci yarısından 1980’lerin başlarına kadar olan süreçte köyden kente olan göçün yarattığı değişim ve buna bağlı olarak gelişen kültürel yapılanmaları resmetmiştir. 1980’li yılların ortalarından itibaren göçün toplumsal etkilerini ele almıs, toplumsal yozlaşma, kültürel etkileşimler, melezleşme, popüler imgelerle birleştirilen simgeler halinde görülmüştür. Sanatç1 1990’lı yıllarda Türk toplumsal siyasal tarihine uzanan çalısmalar yapmış, zorunlu göç, göçün sosyo-ekonomik, kültürel yansımaları gibi konular aynı dönemde yerleştirme ve videolarında işlenmiştir. Sanatçı, sanatın farklı malzeme ve türleri içinde göç ve kültürel kimlik konularını işlemeyi sürdürmüştür (Erdemci vd., 2008, s. 370). Sanatçı "Balkon" isimli çalışmasındaki eklektik yapısından ve stilinin karmaşıklı̆̆ndan bahsetmiştir. Evde, Osmanlı bir objenin bulunduğu düşünülerek yapılan yorumda, ne Osmanlı bilgeliğinin ne de kadın imgesinin yapısı buluşmaktadır. Sanatçı, bahsi geçen eserin yapıldığı dönemden İstanbul'un kalabalıklaşttğı ve sentezlenmiş bir birliktelikten bahsetmiştir. İç göçle Anadolu'dan gelmiş insanların, şehirdeki Art Nouveau tarzında mimarisi oluşturulan yıpranmış apartmanlardaki yaşamlarından kesitleri anlatan eserde, farklı öğelerin oluşturduğu derinliksiz birlikteliklerin geriliminden ya da uzlaşımından faydalanılmıştır (Sağır, 2008: s. 162). Sanatçının göç merkezli çalışmalarında temellenen göç edenlerin yeni yaşam alanına uyum çabaları, kendi kültürünü yaşatma 1srarı ve varılan yerin kendi yaşam dinamikleri arasında kalınan, her iki tarafında gerçekliğinden uzaklaşmış melez bir çelişkili durum dile getirilmiştir.

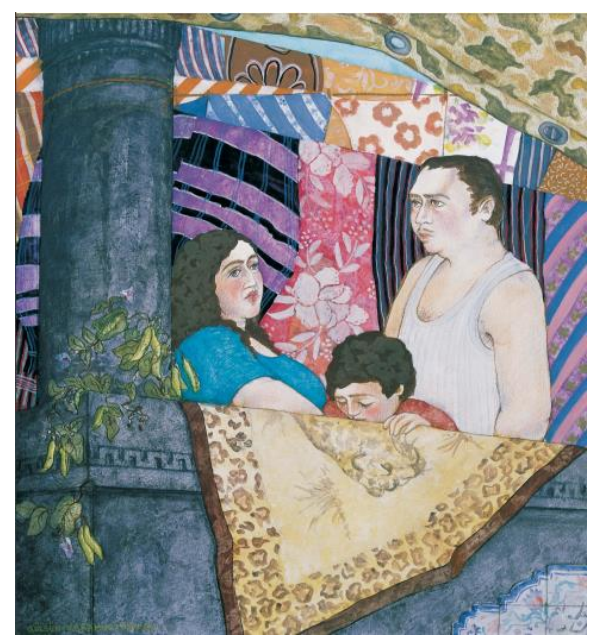

Resim 10. Gülsün Karamustafa, Balkon'dan, $52 \times 57$ cm, Kağıt Üzerine Gwvaş Boya, Suluboya, Renkli Füzen, 1982 (saltonline.org, 2020)

Figür resminde sıra dış1 farklilıkta, kendine has bir üslup yaratan Temür Köran (1960), psikolojik yönü daha fazla hissedilen, kökleşmiş, alşsılmış figür resminin de ötesinde, çizgisini aşan yapitlar üretmektedir. Figürü, daha derin ve simgesel anlamlar yükleyerek yenilemekte ve oluşan yeni anlamlarıly kullanmaktadır (Ersoy, 2004, s. 336). Sanatçının, cesur renk yaratımıyla dikkatleri toplayan tuvallerinde güçlü desen ve yaratıcılı̆̆ın birleşmesiyle oluşturulan coşkun ritim duygusu, renkçi figüratif sanat anlayışının özgün karakterleri olarak yorumlanmaktadır. Sanat tarihinden referanslar bulunan eserleri, çok katmanlı okumalara olanak sağlamaktadır (Kazanç, 2020). Küresel ve güncel olan göç kavramı üzerine çalışmalar yapan Temür Koran, renk, doku ve biçimin ağıllıklı olarak dengeyi kurduğu çalışmalarında 
travmatik bir durumun yarattığı koşulları, yeni anlamları ve ifadeleriyle birlikte insana dair duygulara atıfta bulunarak yorumlamaktadır. "Göç" isimli eserinde yakın zamanda Suriye'de yaşanan savaş ve çatışmadan çıkış bularak, Türkiye'yi de derinden etkileyen evrensel boyuttaki insanlık dramının bir yansıması olan göç olgusu üzerine yoğunlaşmıştır. Dinamik bir görsel anlatım diline ulaştığı çalısmalarının klasik üslubu, plastik değeri yüksek, duygu aktarımının yoğun olduğu çalışmasında, bakış açısının insan ekseninden olduğunu yinelemektedir.

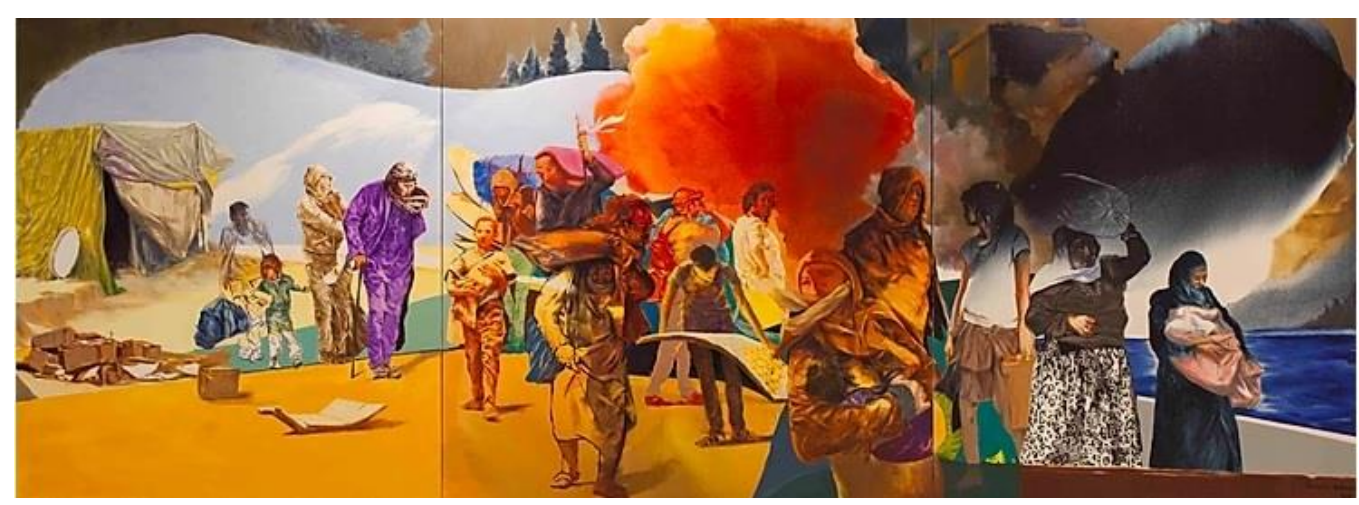

Resim 11. Temür Koran, Gös, $150 \times 410$ cm, T.ü.y.b., 2015, Tüyap Sanat Fuar Koleksiyonu (unlimitedrag.com, 2020)

Tüm zamanlarda, tüm kültür ve coğrafyalarda görülebilecek göç eylemi, toplumdan bağımsız olarak yaşayamayan sanatçılar için bir güdüleme aracı olmuş, çağdaş Türk resim sanatında da yansımaları sıklıkla görülmüştür. Tarihsel süreç içinde dolaylı ya da dolaysız yaşamsal bir belge olma özelliği de olan göç olgusunu eserlerine aktaran birçok sanatçı ismi verilebilmektedir. Bu örnek isimler arasında, köklerine sıkı sıkıya bağlı, geçmişin derin izlerinden beslenen, özünde insanı ve Türk toplumun geçirdiği dönüşümleri ve köklü geçmişini ve bununla birlikte göç konusunu sıklıkla irdeleyen Mehmet Başbuğ güçlü ve yerinde bir temsil olmaktadır.

\section{Mehmet Başbuğ'un Eserlerinde Göç Olgusu}

Çağdaş Türk resim sanatı içerisinde figüratif çalışmalarıyla toplumsal gerçekçi bir çizgide oluşturduğu eserleriyle dikkat çeken Mehmet Başbuğ, Türk insanı ve kültürel değerlerinden beslenerek üretimler yapmıştır. 1956 yllinda Diyarbakır'da doğan Mehmet Başbuğ, Bursa Eğitim Enstitüsü Resim-İş Eğitimi Bölümünden mezun olmuştur. Gazi Üniversitesi, Gazi Eğitim Fakültesi Resim Bölümünde lisans tamamlamıştır. Gazi Üniversitesi Sosyal Bilimler Enstitüsü Resim Ana Bilim Dalında yüksek lisans, sanatta yeterlik ve doktora yapmıştır. Millî Eğitim Bakanlığına bağlı okullarda on yıl görev yapmış, Gazi Üniversitesi Gazi Eğitim Fakültesi Resim Bölümünde Öğretim görevliliği, Isparta Süleyman Demirel Üniversitesi Güzel Sanatlar Fakültesi’nin kuruluş çalışmasında görevlendirilerek Dekan yardımcıllğı ve Resim Bölümü Başkanlığını üstlenmiştir. Devamında Selçuk Üniversitesi Eğitim Fakültesi Güzel Sanatlar Eğitimi Bölümü Resim Ana Bilim Dalı Öğretim Üyeliğiyle birlikte, 2009 yllından vefatına kadar, Kırgızistan Türkiye Manas Üniversitesi'nde eğitimcilik ve Dekanlık görevlerini yürütmüştür. Günümüze kadar yurt içinde ve yurt dışında binden fazla karma ve grup sergilerine katılmış, 90 kişisel sergi açmış, çok sayıda eseri özel ve resmi koleksiyonlarda, müzelerde yer almış, çeşitli resim yarışmalarında ve mesleki anlamda Türk resim sanatına yaptığı katkılardan dolayı yirmi ödüle layık görülmüş ve Türk resim sanatına büyük katkılar sağlamıştır (Başbuğ, 2017).

Yaşamını sanata adamış olan Mehmet Başbuğ’un resim dönemlerini, konu temelinden genel olarak; Anadolu'dan Görünümler, Göç, İstiklal Savaşı, Türk Dünyası İzlenimleri başlıkları altında dört bölümde toplamak mümkündür. Her bir konu alanına birbirinden eşsiz üretimler bırakan sanatçının eserlerinde göç olgusu da ayrıcalıklı yerini almıştır. Sanatçı, Türk Kültürü'nün yaşam damarlarının, beslenme kaynaklarının ardına düşmüş, Türk kültürünün göze çarpan kudretinden etkilenerek çalışmalarını sürdürmüştür. Türk kültürünün renklerini, olgunluğunu, diğer kültürlerden farklı kılan seçkinliğini ve yegâne konumunu ürettiği eserleriyle bugüne taşımıştır. Türk kültür simgelerini bilinçli bir sanat üretim süzgecinden geçirdiği eserlerinde birleştirerek bir gerçekliğin sürdürülebilmesine katkı sağlayıcılık görevi üstlenmiştir.

Mehmet Başbuğ, kendine has üslubuyla görsel durum tespiti yaptığı eserlerinde, yoksulluk edebiyatı yapmamıştır. Sanatçının resimlerindeki az boyayla çok rengin birlikte dansı, müthiş bir gözlemle ortaya harika resimler çıkmasına olanak vermiştir. Günlük yaşamdan seçilen birçok alandaki enstantaneler, canlı bir hayatın göstergeleri olmuştur. Konargöçer Anadolu aşiretleri, sanatçının resimlerinde yaylaya çıkar. 
İnsanlarda heyecanlı bir uğraş, keçilerin gözlerindeki ışık yansımaları, yaylaya çıkmanın mutluluğu, Başbuğ’un eserlerinde insanlar ve hayvanlar için değişmez bir süreci kapsamıştır (Tepecik, 2017, s. 74). Başbuğ un resimlerinde plastik unsurları ve ilkeleri tek başına önceleyen bir anlayıştan öte nesneleri kuşatan bir Anadolu kültürünün varlığ1 hissedilmektedir. Resimleri, kompozisyon, renk ve kurgu bakımından özel bir coğrafyayı işaret etmekle birlikte, arka planda soyut gizemlerle dolu, destansı bir anlatım ve yaşam dilini çağrıştırmaktadır. Göçler, göçebe bir hayatın gereğinden ziyade savaşların, kıtlık ve yoksulluğun zorunluluğu gibidir. Ancak her şeye rağmen, bu resimler inancin ve baş eğmezliğin birer temsili isyanı niteliğindedir (Altıntaş, 2017, s. 68).

Çağdaş Türk Resim Sanatında figüratif çalışmalarıyla yeri mühürlenen sanatçının resimlerinde göç olgusunun kayda değer bir yeri olduğu açıç̧a görülmektedir. Kültürlerin, toplumların en vazgeçilmez varlık sebebi olduğu bilincinden hareketle, Türk kültür ve değerlerinden, içinde bulunduğu toplumun geçmişinden beslenerek, hür ve üstün üretimler yapmış, Türk kültür gerçeklerini yansıtmıştır. Çoğunlukla göç sürecindeki anlık görüntüleri, öncül ve ardıl psikolojik yansımasıyla aktardığı göç konulu eserlerinde, kendine has oluşturduğu üretim karakterinin çerçevesinde yorumladığı dinamik formların özgün sanatsal diliyle yapıtlarına aktarıldığı görülmektedir. Kalabalık insan figürlerinin kullanıldığı eserlerinde, güçlü desen yapısı kompozisyonun bel kemiğini oluştururken; tercih ettiği renkler ve kurgu düzeni, bir gerçeğe tanıklık eden ve gelecek kuşaklara aktarılacak belgelere dönüşmüş ve sanatçının yapıtlarının eşsiz prototipini ortaya koymuştur.

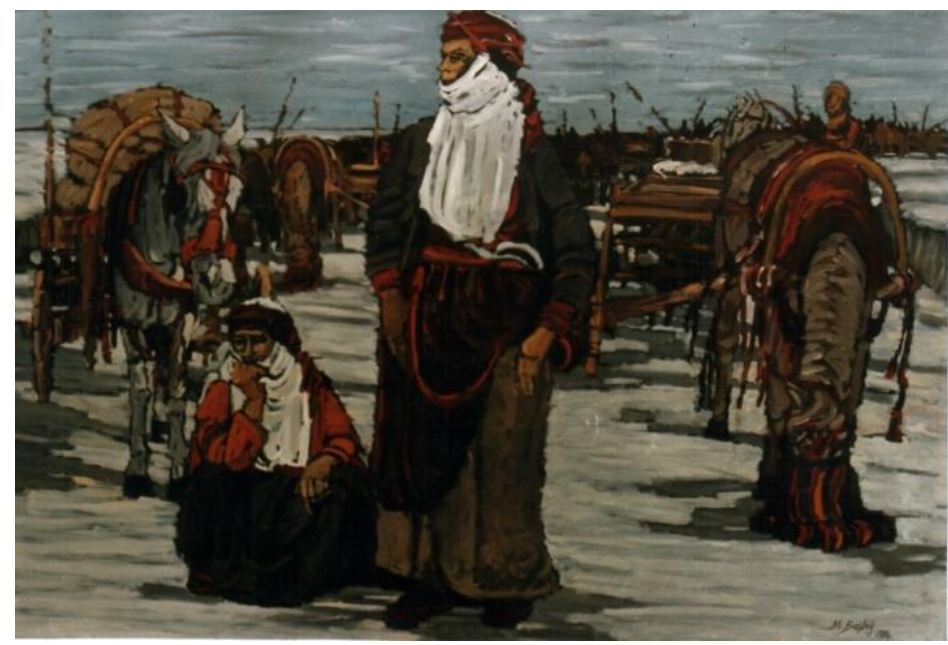

Resim 12. Mehmet Başbuğ, Göc, 140×200 cm, T.ü.y.b., 1984 (Özel Koleksiyon)

Mehmet Başbuğ’un 1984 tarihli "Göç" isimli eserinde, izleyicinin göç anına tanıklık etmesi sağlanmıştır. Yapısı itibariyle sarsıcı bir yanı olan göç, önde duran iki figürden yere çökmüş olanının üzerinden rahatlıkla okunabilmektedir. Uzun bir göç kervanının bir kesitini oluşturan resimde, birliktelikten doğan ruh, grubun eylem dinamizmini yapılandırırken, lekelerle elde edilen 1şık-gölge değerleri figürlerin mekânla birlikte dengeli bir şekilde yerleşmelerine olanak sağlamıştır. Eserde planlar itinayla yerleştirilirken, insan yaşam kültür ilişkisi estetik bir düzeyde sunulmuştur. 


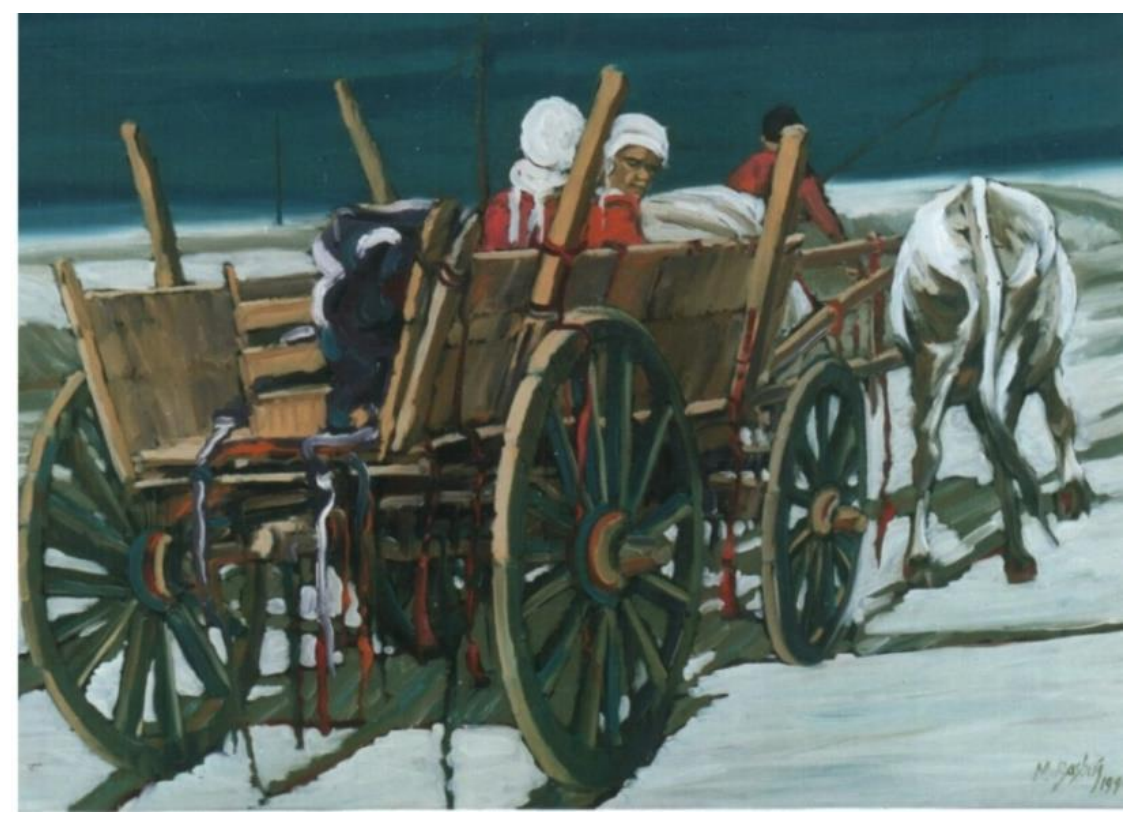

Resim 13. Mebmet Başbuğ, Göç, $80 \times 100$ cm, T.ü.y.b., 1990, Özel Koleksiyon (mehmetbasbug.com.tr, 2017)

Sanatçının 1990 yllında ürettiği "Göç" isimli eserinde, oldukça karmaşık bir olgunun ruhsal olarak geride bırakılanlara belki de kaybedilenlere bir atıfın yansımaları görülmektedir. Başbuğ'un eserlerinde acının, kahrın, ötelenmişliğin, çilenin, unutulmuşluğun, çaresizliğin, fukaralığın, öfkenin rengi ve kokusu insan tiplerinin yüzlerinden, kıyafetlerinden çıkarılabilmektedir. Ancak aynı zamanda umut ve hayata tutunma çabası da çözümlenebilmektedir (Şehsuvaroğlu, 2017, s. 43). Kağnı üzerinde giden figürler arasındaki geriye doğru bakan figürün yüzündeki ifade, göç yapmanın zorlu şartlarını izleyicisine sunmaktadır. Kendi kültürlerinin giysileri içinde olan figürler sanatçının belirgin üslubundaki renk seçimiyle vurgulanarak, dramatik bir gerçeklik çarpıcı bir olgunlukta izleyicisine sunulmuştur.

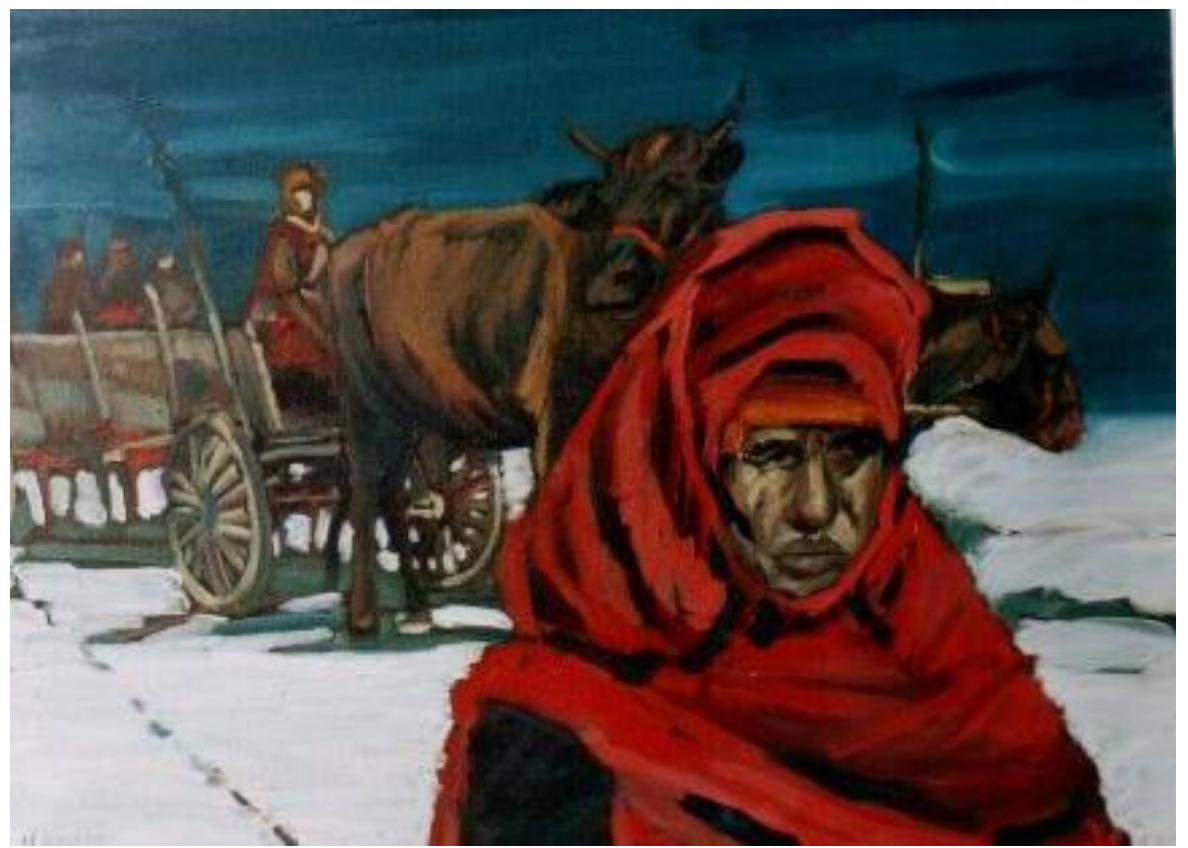

Resim 14. Mehmet Başbuğ, Gös, $50 \times 60$ cm, T.ü.y.b., 1991 (Özel Koleksiyon)

Sanatçının 1991 tarihli "Göç" isimli yapıtı önde yer alan ana figür ve arka planda yer alan diğer figürlerle oluşturulmuştur. Sanatçının eserlerinde ön planda tüm yüz çizgileri ile tam bir karakter analizi yer alırken, arkaya doğru perspektif ilk planda verilen duyguyu arttırarak devam ettirmektedir (Açıkgöz, 2017, s. 54). Sanatçının çoğunlukla figürlerini betimlerken tercih ettiği yanık buğday ten, ön plandaki figürün yüzünde uygulanmıştır. Figürün resim düzlemi üzerine yerleştirildiği alan, çalışmaya yumuşak bir ritim katarken, figürün hareketli bir görünüm kazanmasına da olanak vermiştir. Birçok değişkeni içinde 
barındıran göç olgusunun kasvetli yapısı arka planda kullanılan mavi tonlarıyla güçlendirilirken, renk kontrastlarıyla oluşturulan uyumlu birliktelik sanatçının üslup kimliğinin yansımaları olarak sunulmuştur.

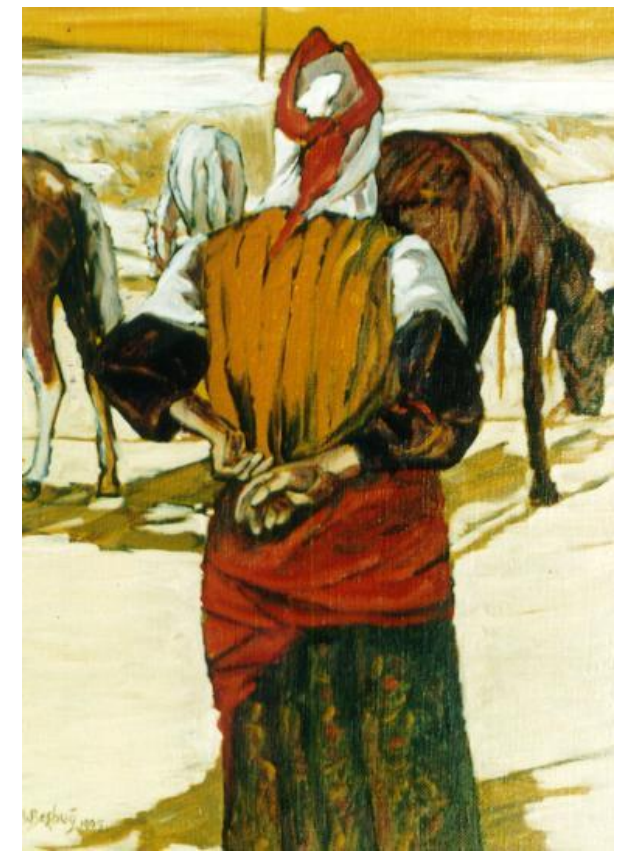

Resim 15. Mehmet Başbuğ, Yörükler, $70 \times 50$ cm, T.ü.y.b., 1995 (Özel Koleksiyon)

1995 yllında ürettiği "Yörükler " isimli eserinde sanatçı, Yörük yaşamından seçtiği görüntüyü kendine has üslubu içinde biçimlendirmiştir. Konar-göçer olarak nitelendirilen zorlu yaşam koşullarını, sosyal yaşamı ve mücadeleyi büyük bir özenle aktardığı çalışmalarında yaşama dair çizgisel notlar düştüğü görülmektedir (Başbuğ, 2016, s. 22). Yüzyllarca hayvancllıkla geçimlerini sağlayan Yörüklerin yaşam tarzında devinimsel olarak hava şartlarına göre yüksek ve alçak bölgelere göçme eylemi vardır. Geniş bir mekanda biçimlenen resim içinde büyük bir alana yerleştirilen kadın figürü arkadan bir elini ters tutarak beline koymuş, diğer elini belinin yan tarafina yerleştirmiş olarak betimlenmiştir. Saf bir duyarlllık ve samimi bir insan sevgisinin sunulduğu eserde arka plandaki otlanan atlar Yörük yaşamının vazgeçilmez bir gerekliliği içinde verilmiştir. Kadın karakterlere de eserlerinde sıklıkla yer veren Başbuğ, kadının yaşam içinde ayakta durma çabasına ve her şeye rağmen umut içinde yaşadığına gönderme yapmaktadır.

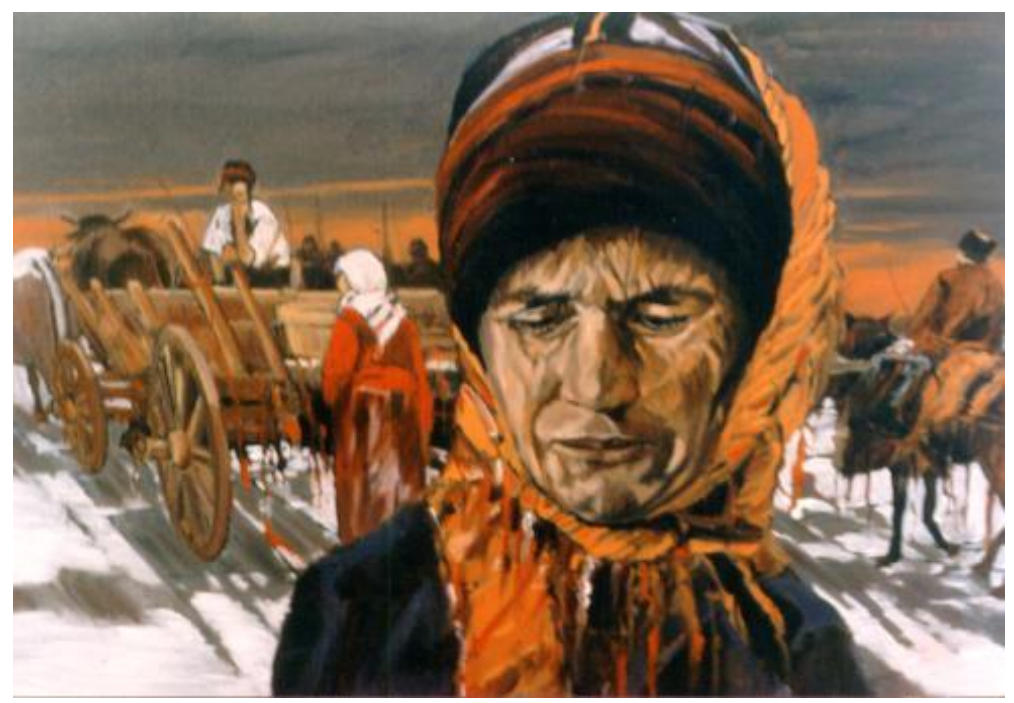

Resim 16. Mehmet Bassbuğ, Portre, $80 \times 100$ cm, T.ü.y.b., 1996 (Furat Üniversitesi Koleksiyonu)

Sanatçının klasik kurgu düzeninde oluşturduğu 1996 tarihli "Portre" adlı eserinde, göç eden insanların yaşadığı ruhsal durumu somutlaştırılmış bir halde betimlenmiştir. İnsanı ön plana alan çalışmalar yapan sanatç1, figüre, güçlü desenin gerekliliklerine uyumsayarak bağlllık göstermiş ve portreleri iyi birer 
ruhsal durum yansıtıcı görevi görmüştür. Dikkatli bir gözlemci olarak ürettiği çalışmasında göç temasını dolaysız olarak yorumlamış, seçtiği hiçbir öğe diğerinden daha az önemsiz olmamış ve kullanılan her bir figür resmin anlamını güçlendirirken kompozisyon içinde kendini var etmiştir.

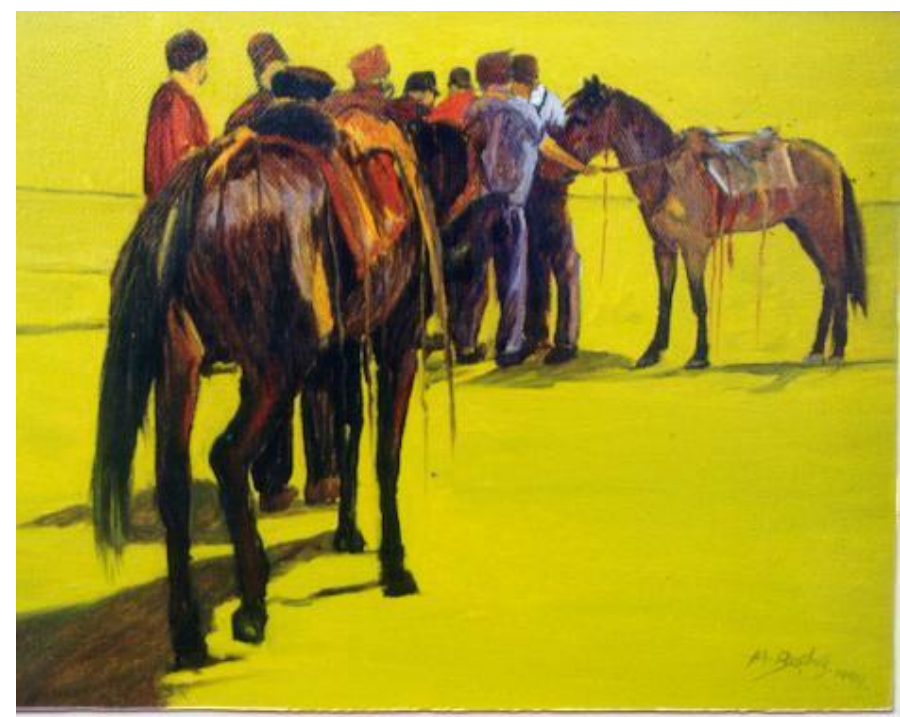

Resim 17. Mehmet Başbuğ, Göscrler, $40 \times 50$ cm, T.ü.y.b., 1998 (Özel Koleksiyon)

Başbuğ’un 1998 yllında ürettiği "Göçerler" adlı eserinde, sade bir mekân içinde yer alan at figürü arkasından bakılarak ön planda tutulmuş ve uygulanan renk seçimiyle at ve insan figürlerinin üzerinde yorumlanan firça darbeleri resme dinamizm katmıştır. Resimlerinin kaynağını Türk insanından ve yaşamından alan sanatçı kullandığı imgelerinde hayatın akışkan izlerini sunmaktadır. Yapıtlarında izleyiciye doğru gelen ya da tam tersi uzaklaşan figürleri görebilmenin mümkün olduğu çalş̧malarına bir örnek olan bu eserinde, göçerlerin yol aldığı ancak bir durum için durduklanı izlenimi verilmiştir. Yörük yaşantısında önemli bir yeri olan insan ve at arasındaki ilişkinin de yansıtıldığı eserde, at figürleri de nesnel biçimiyle yansıtılmıştır.

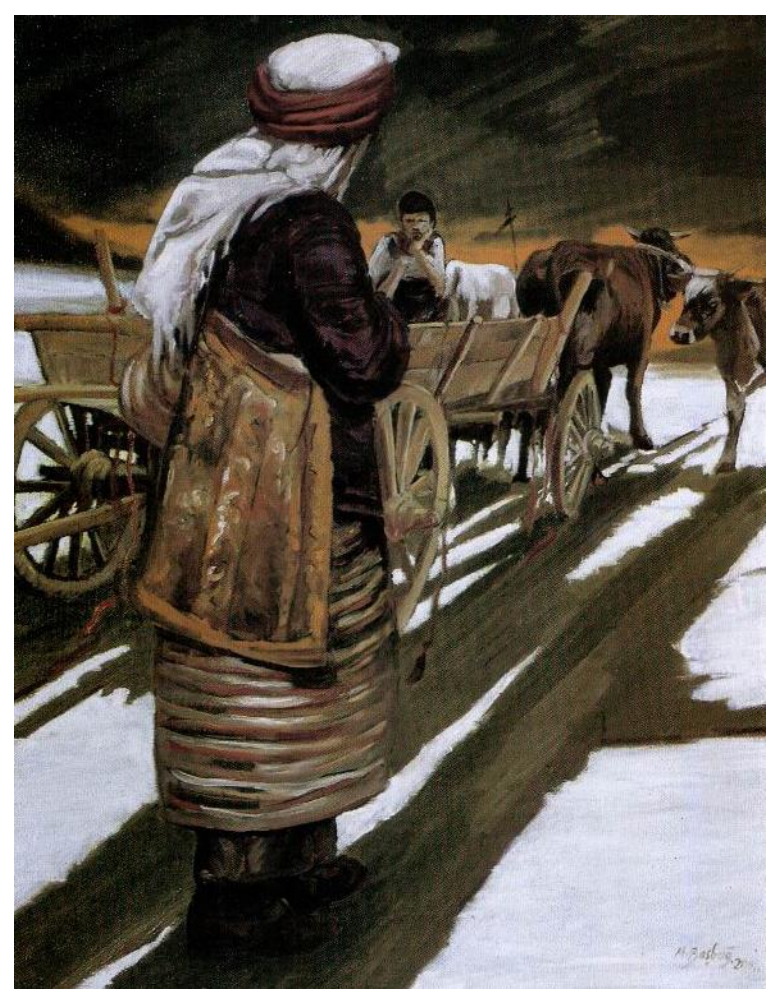

Resim 18. Mehmet Başbuğ, Gös, $110 \times 90$ cm, T.ü.y.b., 2001 (Özel Koleksiyon)

Mehmet Başbuğ, 2001 yılında ürettiği "Göç" isimli çalışmasında, ağırlıklı olarak kahverenginin tonlarını kullanarak resmini oluşturmuştur. Zeminde beyaz renk kullanılırken, gökyüzünde koyu renk 
tonları kullanılmıştır. Ancak bu yaklaşım gölgeleriyle birlikte verilen figürün daha da ön plana çıkmasını sağlayan ve biçim-öz ilişkisini kuvvetlendiren bir amaca hizmet etmiştir. Kağnı üzerinde başını ellerinin arasına alan figür ile ön planda sırtı dönük, hareketine yeni başlayan figür karşı karşıya gelmiştir. Zeminde kullanılan lekeler izleyicinin gözündeki sürekliliği arka planlara doğru sürüklemiş ve geleceğe dair umutlu beklentilere gönderme yapmıştır. Yönleri birbirlerine doğru olan figürlere arkadaki öküzlerden birinin de dahil olmasıyla oluşturulan üçgen yapıda insan hayvan ve doğa ilişkisi vurgulanmış ve hayvanlarla alınan bu yolun ne kadar meşakkatli bir süreci gerektirdiğinin altı çizilmiştir.

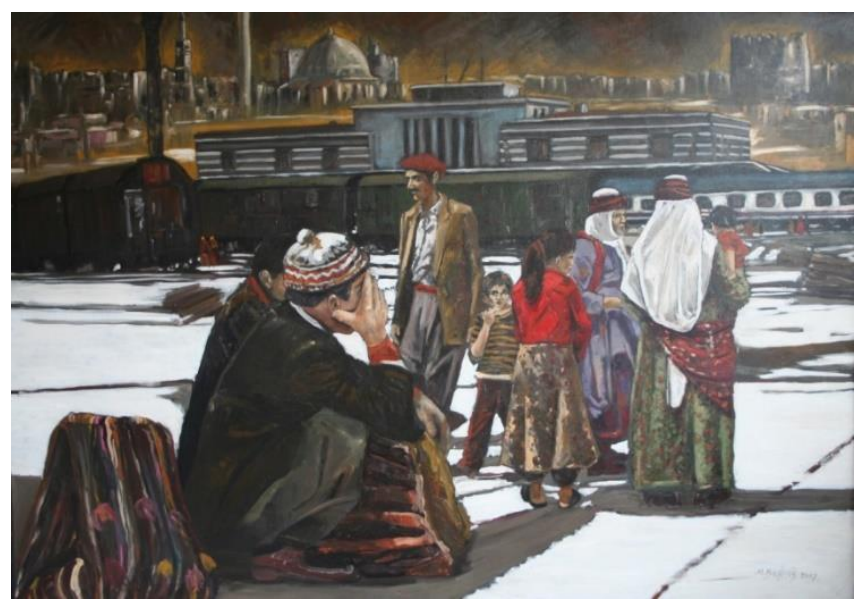

Resim 19. Mehmet Başbuğ, Diyarbakır Tren İstasyonu, $140 \times 200$ cm, T.ü.y.b., 2007 (Türkiye Cumburiyeti Devlet Demir Yollar Koleesiyonu)

Başbuğ’un 2007 yılında yaptığı "Diyarbakır Tren İstasyonu” isimli eserinde, bu çalışmada örneklenen eserlerindeki kurgularından daha farklı bir mekân içinde çalışmasını gerçekleştirdiği görülmektedir. Bir Anadolu şehrinden görüntülenen eser, bölgeyle ilgili imgeleri bize sunmaktadır. Arka plana yerleştirilen şehre ait dokular, trenlerin yer aldığı bölgeden itibaren kesilerek koyu renk tonları kullanılarak sınırlandırılmış bir etki yaratsa da resmin bütünlük değerini yükseltmekte ve çalışmaya derinlik katmaktadır. Eserde 1şık ve renk firça hareketlerinin hızlı yol alısıına rağmen figürlerdeki durgunluk, göç sürecindeki bekleme anına gönderme yapmaktadır. Yöresel kıyafetlerin, yardımcı malzemelerin özenli bir şekilde işlendiği esere, taze renk kullanımı canlı bir görüntü oluşturarak izleyiciyi zamanın tanığ1 konumuna taşımaktadır. Arka plandaki kadın figürler arasındaki sürece dair belirsiz bekleyiş ön planda yer alan başını eline yaslayan erkek figürün gergin bekleyişiyle örtüşmektedir. Resmin göstergelerinin değerini arttıran kontrast renk seçimleri figürlerin hareketleriyle güçlenerek, göçle ilgili duygu yoğunluğunu yücelten itici kuvvetlere dönüşmektedir.

\section{Sonuç}

Sanatsal çalışmalar, siyasi, iktisadi, kültürel ve sosyal parametrelerden etkilenmekte ve insanı merkeze alan tüm alanlardaki gelişmelerin birer toplumsal yansımasına ayna tutmaktadır. İnsanın yaşamında dolaylı ya da dolaysız yer tutan göç olgusu, sanat alanı içinde de güncelliğini hep taze tutmuş çalışma alanlarından biri olmuştur. Çağdaş Türk sanatının resim alanındaki üreticilerinin göç olgusunu ele alan eserleri incelendiğinde, biçim içerik bakımından zengin ve kalıcı eserlerin sanat tarihinde derin izler bıraktı̆̆1 görülmektedir. Farklı anlatım yaklaşımlarılla çalışılan göç olgusunun sosyolojik, psikolojik, kültürel gibi birçok yönüyle ele alındığı ve yorumlandığı görülmektedir. Toplumun içinde doğal bir üye olan sanatçı için göç olgusu, kimi zaman göç öncesi yaşanan duygu durumları olarak ele alınmakta, kimi zaman göç anının sanatsal kesitleri olarak sunulmakta, kimi zaman ise göç sonrası yaşanan gelişmeler paralelinde sanatsal duyarllı1kta aktarıldığı görülmektedir. Göç olgusunu irdeleyen Türk resim sanatındaki bu seçkin eserlere ihtişamlı bir servet bırakan Mehmet Başbuğ; sanata, insana, yaşadığı ve yetiştiği coğrafyaya duyarlı bir sanatç1 olarak üretimler yapmıştır. Sanatçının nesnel dünyada gördügüu, içinde bulunduğu kültürün geçmişinin izlerinden içselleştirdiği olayları ve yaşanmışlıkları, kendi bireysel üslubunda yarattı̆̆ sanatsal imgelere dönüşmüştür. Türk yaşam tarzından ve kültüründen beslenerek insanın yaşam mücadelesinin altını çizen sanatçı, göç olgusunu irdelerken çoğunlukla göç anından enstantaneler vermiştir. Göç olgusunu çalıştı̆̆ eserlerinin üretim tarihleri göze alındığında, belirli aralıklarla devinimsel olarak aynı tema üzerinde çalıştı̆̆1 görülmektedir. $\mathrm{Bu}$ istikrarlı tutum, sanatçının doğduğu, yetiştiği, yaşanmışlığının olduğu coğrafyadan ve köklerinden ne kadar etkilendiğinin önemli göstergeleri arasında görülmektedir. Yöresel 
kıyafetleri içinde kültürün sunduğu renkleriyle yerlerinden kopan insan figürleri, içinde bulunulan ruhsal yapısıyla birlikte sanatçının özgün üslubunda anlam kazanmıştır. Figürlerin yüzlerinden okunan göçe dair zorlu sürecin yarattı̆̆1 olumsuz duyguların aksine, insanın hayata bağlanmasında önemli bir unsur olan umut çalışmalarının en önemli alt göstergeleri olarak sunulmuştur. Güçlü bir desen ve kompozisyon bilgi ve deneyimine sahip olan sanatçı göç resimlerinde insan figürlerine ek olarak tamamlayıcı objelerle özellikle özel bir hassasiyeti olan atın da bulunduğu birçok hayvan figürünü resmin içerisine almıştır. Ürettiği yapıtlarıyla gelecek kuşaklara benzeri olmayan kültürel bir belge sunarak, yüklendiği yol göstericilik ve kültür aktarıcılık görevini manevi bir haz duygusuyla aldığı açıkça yorumlanabilmektedir. Eserlerinde hiç bir abartıya kaçmamış olan sanatçının bir gerçekliği sunduğu ve bunu gerçekleştirirken görsel zenginlik ve birikim içeren sanat anlayışıyla yaptı̆̆ görülmektedir.

\section{Etik Beyan}

"Çağdaş Türk Resim Sanatında Göc Olgusu: Mehmet Başbuğ Özelinde Bakmak”" başlıklı çalışmanın yazım sürecinde bilimsel, etik ve alıntı kurallarına uyulmuş; toplanan veriler üzerinde herhangi bir tahrifat yapılmamış ve bu çalışma herhangi başka bir akademik yayın ortamına değerlendirme için gönderilmemiştir.

\section{Kaynakça}

Açıkgöz, N. (2017). Kırmızı'nın ressamı Mehmet Başbuğ’un ardından. Türk Edebiyatı Ayllk Fikir ve Sanat Dergisi, 526, 53-54.

Altıntaş, O. (2017). Tanrı dağları sonsuza kadar yaslı kaldı. Türk Yurdu Dergisi, 360, 68-69.

Atan, A. (2019, 14 Kasım). Sanat ve Göç. Ahmet Atan. Erişim adresi: http://ahmetatan.com/?p=73.

Aygül, Hasan Hüseyin (2018). Mülteci emeğinin Türkiye işgücü piyasalarındaki görünümü ve etkileri. Süleyman Demirel Üniversitesi Visyoner Dergisi, 9(20), 68-82. doi:10.21076/vizyoner.369358

Başbuğ, F. (2016). Mehmet Başbuğ - Bozkerdaki atlar/ desenler. Adana: Yeni Doğuş Matbaacilık.

Başbuğ, M. (2017, 09 Mayıs). Özgeçmiş. Mebmet Başbŭ̆g. Erişim adresi: http://mehmetbasbug.com.tr.

Berk, N. (1972). İstanbul resim ve heykel müresi. İstanbul: Akbank Yayınları.

Erdemci, F., Germaner, S. ve Koçak, O. (2008). Modern ve ötesi 1950-2000. İstanbul: Bilgi Üniversitesi Yayınları.

Ersoy, A. (1998). Günümür Türk resim sanatz (1950'den 2000'e). İstanbul: Bilim Sanat Galerisi.

Ersoy, A. (2004). 500 Türk sanatgcss plastike sanatlar. İstanbul: Altın Kitaplar Yayınevi ve Ticaret A.Ş..

Fichter, J. (1996). Sosyoloji nedir?, (Çev: N. Çelebi). Ankara: Attila Kitapevi.

Giray, K. (2000). Türkiye Iss Bankası resim koleksiyonu. İstanbul: Türkiye İş Bankası Kültür Yayınları.

Gönülal, Ö. (2007). Sanat Kavramı ile İç Göç İlişkisi Üzerine Düşünceler. Sanat Teorisi. Erişim adresi: http:/ $/$ www.sanatteorisi.com/sanatteorisi.asp?sayfa $=$ Makaleler\&icerik $=$ Goster\&id=2695.

Gültekin, G. (1992). Batı anlayışında Türk resim sanatı. Ankara: T.C. Ziraat Bankası.

İşanç, Y. (2008). Yeni Türk gerçekçiliği ve Nedim Günsür (Yüksek Lisans Tezi). Trakya Üniversitesi Sosyal Bilimler Enstitüsü, Edirne.

Kaya, İ. (2008). Avrupalı Türkler: Misafir işçilikten Avrupa vatandaşlı̆ına. Doğu Coğrafja Dergisi, 13(19), 149-166.

Kazanç, Ü. (2020, 19 Ocak) Temür Köran: Göç. Unlimitedrag. Erişim adresi: https://www.unlimitedrag.com/post/temur-koran-goc.

Marshall, G. (1999). Sosyoloji sözliügü (Çev: O Akınhay ve D. Kömürcü). Ankara: Bilim ve Sanat Yayınları.

Öner, F. K. (2016). Çağdaş Türk resim sanatında göç teması: Ramiz Aydın örneği. İçinde A. Tillbe ve S. Bosnalı (Edt.), Gọ̈ üzerine yažn ve kïltür incelemeleri (ss. 41-54). London: Transnational Press London.

Özer, İ. (2004). Kentlesme, kentlilessme ve kentsel değgisme. Bursa: Ekin Kitabevi.

Sağır, Ç. (2008). Gülsün Karamustafa. İçinde İ. Duben ve E. Yıldız (Edt.), Seksenlerde Türkizye'de gağdass sanat: Yeni açlimlar (ss. 158-179). İstanbul: İstanbul Bilgi Üniversitesi Yayınları.

Sağlam, S. (2006). Türkiye'de iç göç olgusu ve kentleşme. Hacettepe Üniversitesi Türkiyat Araștrmalar Dergisi, 5, 33-44.

Şehsuvaroğlu, L. (2017). Mehmet Başbuğ: Asım’nn Neslinin resmi, Türk Edebiyatı Ayllk Fikir ve Sanat Dergisi, 526, 4246.

Şen, M. (2014). Türkiye'de iç göçlerin neden ve sonuç kapsamında incelenmesi. Calş̧ma ve Toplum, 1, 231-256.

Taş, H. Y. ve Özcan, S. (2013). Türkiye'de iç göçün yoksulluğa ve istihdama etkileri. İçinde S. Sarr, A. H. Gencer ve İ. Sözen (Edt.), International Conference On Eurasian Economies (ss. 289-298). St. Petersburg - Russia, Türkiye: Beykent Üniversitesi.

$\begin{array}{llll}\text { TDK. } & \text { 2019, Aralk). Adresi: }\end{array}$ http://www.tdk.gov.tr/index.php?option=com_gts\&arama=gts\&guid=TDK.GTS.5c80385dc4e333.43762600.

Tepecik, A. (2017). Anadolu'dan Tanrı Dağları'na, insanların ve atların ustası, Prof. Dr. Mehmet Başbuğ, Türk Yurdu, $360,70-75$. 


\section{Görsel Kaynaklar}

Balaban, H. N. (2011). Balabanizm İbrabim Balaban. International Art Center Sergi Kataloğu. İstanbul: Bilnet Matbaacılık Kataloğu.

Balkon'dan Eser Görseli (2020, Ocak 15). Erişim Adresi: https://saltonline.org/media/files/duskun-ikona_scrd1.pdf.

Gecekondular Önünde Eser Görseli (2020, Ocak 16). Erişim Adresi: http://www.nuriiyem.com/eser/s1137-028/.

Göç Eser Görseli (2019, Aralık 3). Erişim http:/ /www.turkishpaintings.com/index.php?p=34\&l=1\&modPainters_artistDetailID=217.

Göç Eser Görseli (2020, Ocak 16). Erișim Adresi: http://www.nuriiyem.com/eser/s1137-007/.

Göç Eser Görseli (2020, Ocak 19). Erişim Adresi: https://www.unlimitedrag.com/post/temur-koran-goc.

Göçebeler Eser Görseli (2019, Ekim 11). Erişim Adresi: https://www.istanbulsanatevi.com/turk-ressamlar/huseyinbilisik-hayati-ve-eserleri/.

Karkıner, N. ve Ecevit, M. (2012). Neşet Günal'ın izinde Türk resminde tarımda kadın imgesi: sosyolojik bir çözümleme. Uluslararası Kıbrıs Üniversitesi Folklor/Edebiyat Dergisi, 18(69), 207-243.

Satılmış, S. (2019). Turgut Zaim'in resimlerinde renk sembolleri kullanım ve minyatür etkisinin incelenmesi (Yüksek Lisans Tezi). Altınbaş Üniversitesi Sosyal Bilimler Enstitüsü İstanbul.

Tansuğ, S. (2005). Cağdaş Türk sanatı. İstanbul: Remzi Kitapevi.

Yeşil Tren / İstanbul - Frankfurt Eser Görseli (2020, Ocak 15). Erişim Adresi: https://blog.peramuzesi.org.tr/wpcontent/uploads/2013/11/akmed_001713.jpg.

\section{EXTENDED ABSTRACT}

The migration, which has existed since the earliest periods in human history, has been one of the domains that guide society under many variables. The migration that has been reflected on many geographies continues to have an effect in the past and today, but is among the situations that are likely to show its presence in the future. The migration, a space replacement process in the most general sense, can be subjected to many classifications. Although migration can be divided into voluntary or forced types, it is noted that there is a complex process in its essence. In migration, it is often thought that the main determinant is economic, and it is seen that the change in living standards as a harness is also effective. As a result, it is inevitable that the emigrant individual or group will take their share of various interactions. The most important result of cultural migration is the spread effect. Contacting the existing community and migrants opens the door to a new communication system. A classification can be reached in the form of internal and external migrations. The type of migration within a country's borders is called domestic migration, while what is done outside a country's borders is called foreign migration. The factors that cause migration are considered repulsive and attractive factors in their analysis. Considering the history of migration in Turkey, the movements that took place since the 1950s were mostly from village to city, since the 1980s, the course of migration has changed, and it has been shifted from large cities to metropolitan areas more. It is noted that the concepts of urbanization and squatting are also emerging with migration. After the exchange, which was an important population movement in the foreign migration process, the migration of workers after the agreement with European countries constitutes important parts of mobility. Although the civil war and conflicts in Syria in recent times have led to intense immigration and the process is still ongoing, the migrations received by Turkey due to the occasion of conflict, turmoil and economic reasons in the vicinity and as a transitional country in terms of migration can be listed as factors that affect migration mobility in Turkey. Today, it is seen that migration mobility has profoundly affected the social structure. Migration contains a reality within life as the whole of relationships that have no easy explanation. As a case that has been incorporated into the Turkish structure, migration is a historical event in which they carry their traces. The life of plateau and barracks became important in Turks, comprising of a rich tradition, and Turks carried out their most basic migration actions in summer and winter in the form of transformation. Migration refers to a process that affects, transforms and is affected by elements such as political, economic, social and cultural factors. The equipment of civilization, which is culturally carried through migration, affects life dynamics of the place where to settle, while at the same time it is mutually affected. An intercultural interaction occurs through migration. The new place to live for an individual or group that is disconnected from the order of migration, which is a complex lump of relationships, requires new meanings to be gained. This form of action that leads to the transformation of an individual constitutes the values of a past experience that creates permanent traces of memory. Some migrations may contain many human emotions in accordance with the meaning that the individual has imposed on these migrations. Considering at case of migration on an axis that centered on human beings, 
it has become inevitable for an artist living in a social order to reflect this situation on his artistic sensibility. Sometimes an artist finds his point of origin by feeding on his life and testimony, sometimes from historical references, and sometimes from his inner sensibility. The case of migration that is discussed in many art disciplines such as cinema, theater and sculpture, provides the most distinguished examples of contemporary Turkish painting. Causalities created by migration are presented with an aesthetic sensitivity and through subjective approaches to individual art practices by artists. The works presented along with many riches on this focused theme axis represent the difficulty of living conditions, often burdened with the difficulty of obstacle process. In some works, the migration process is presented with all its nudity and dramatic aspects, while in some works it is discussed with strength. Similarly, in these works, sometimes pre-migration process, sometimes a cross-section of the migration moment, and sometimes the developments that occurred after migration are depicted. Turgut Zaim, Nuri İyem, ibrahim Balaban, Nedim Günsur, Ramiz Aydin, Gulsün Karamustafa, Temür Köran and many valuable names who draw attention to the issue of migration in contemporary Turkish painting art and produce works with this sensitivity stand out in this context. It is observed that the case of migration, discussed with various narration possibilities, is interpreted in many aspects and with its rich equipment in terms of format and content. In this respect, since these works are produced as an indirect or direct vital document and they act a mirror of society, their importance increases. Mehmet Basbug is a valuable name who studies migration, connects his past and roots by clamping down on his past and roots, turns his direction to people, examines the transformations and noble past of Turkish society and often gives works on migration. Basbug presented the subject as the outputs of a qualified cultural knowledge and artistic work in which he emphasized with the figures he used in his personal interpretations with a strong composition and pattern infrastructure. Basbug has transformed the events and experiences he witnessed in the objective world, assimilated from the traces of his own culture, into images created by his personal style. Emphasizing the struggle for the life of the Turkish people, the artist often depicted cross-sections from the moment of migration while examining the case of migration. In his artistic life, it is seen that Basbug concentrates on the issue of migration alternately at regular intervals. This consistent approach is proof of how much he is affected by his roots. Human figures who migrate with their local clothes and cultural colors find meaning in the nature of the mental state experienced under difficult conditions. Despite the hard-fought footsteps of faces of the figures, hope is always highlighted as an element that retains its freshness. Using additional complementary elements to human figures in migration paintings, the artist, Mehmet Basbuğ, has left a cultural heritage with no other precedent for future generations. His guiding and cultural emitter takes his position with a spiritual responsibility and pleasure. Visual accumulation and wealth are clearly seen as a saturated national archive with Basbug's works that give the nature of documents that bear witness to a reality such as migration that has an important place in Turkish culture. 